\title{
A Field-Based Technique for Measuring Sediment Flux on Coral Reefs: Application to Turbid Reefs on the Great Barrier Reef
}

\author{
Nicola K. Browne ${ }^{\dagger}$, Scott G. Smithers ${ }^{\dagger}$, Chris T. Perry \\ School of Earth and Environmental Sciences \\ James Cook University \\ Townsville, Queensland 4811, Australia \\ Department of Geography \\ College of Life and Environmental Sciences \\ University of Exeter \\ www.cerf-jcr.org
}

nicola.browne@my.jcu.edu.au

Exeter EX4 EPS, United Kingdom

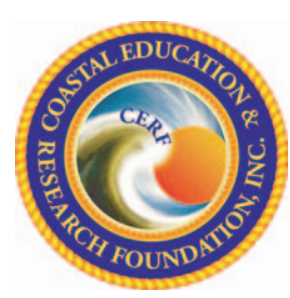

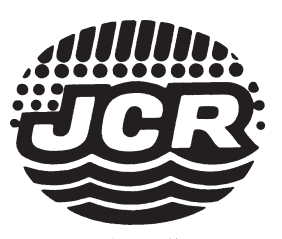

www.JCRonline.org

\section{ABSTRACT}

Browne, N.K.; Smithers, S.G.; Perry, C.T., and Ridd, P.V., 2012. A field-based technique for measuring sediment flux on coral reefs: application to turbid reefs on the Great Barrier Reef. Journal of Coastal Research, 28(5), 1247-1262. Coconut Creek (Florida), ISSN 0749-0208.

Inshore turbid reefs on the Great Barrier Reef (GBR) are exposed to high and fluctuating sediment loads normally associated with poor reef growth, but many have high coral cover $(>30 \%)$ and diversity $(>50$ species). Previous assessments of sediment regimes on these reefs have largely relied on sediment trap data, which overestimate sedimentation rates and may not accurately reflect sedimentary conditions. A new approach, based on paired sediment trays, is described here that allows the sedimentation rate, sediment resuspension, and total mass of mobile sediments transported on to and off of a site per unit time and area (termed the two-way total sediment flux) to be measured or calculated. The sediment trays were deployed on Middle Reef and Paluma Shoals, two inshore turbid reefs on the GBR where the two-way total sediment flux ranged from $34 \mathrm{~g} / \mathrm{m}^{2} / \mathrm{d}$ in protected reef habitats to more than $640 \mathrm{~g} / \mathrm{m}^{2} / \mathrm{d}$ in higher-energy settings. Mean sedimentation rates, calculated using data from four sites across these reefs, of less than $122 \mathrm{~g} / \mathrm{m}^{2} / \mathrm{d}$ are considerably lower than published rates estimated for nearby coral reefs, largely because sediment traps limit sediment resuspension. At each tray installation, sediments were collected every 4 to 6 weeks to measure variations in net sedimentation through the year, and resuspension rates were calculated by comparing $100 \mathrm{~g}$ of preanalysed sediments placed on trays at deployment to sediments recovered 2 weeks later. These data demonstrate that despite high sediment delivery rates, net sedimentation may still be relatively low and potentially less of a threat to benthic communities on turbid reefs than previously assumed. Sediment trays provide a comprehensive assessment of sediment regimes that, together with ecological assessments of coral cover, improve our understanding of the sedimentary pressures affecting inshore turbid reefs and their ability to tolerate sedimentation.

ADDITIONAL INDEX WORDS: Sedimentation, sediment resuspension, turbidity, community assemblages.

\section{INTRODUGTION}

Detailed knowledge of sediment regimes is required to understand how marine ecosystems respond to high sediment loads. Excessive sediment loads can negatively affect coastal coral reefs when they form a suspended load, which increases turbidity and limits light penetration to depth (Rogers, 1990; Wolanski and De'ath, 2005), or when sediments are deposited and smother reef benthos (Loya, 1976). The inshore reefs of the Great Barrier Reef (GBR) are exposed to high sediment loads (Devlin and Schaffelke, 2009; Wolanski et al., 2005; Wolanski et al., 2008; Woolfe et al., 1998) and as such are widely perceived to be degraded systems with low coral cover and diversity (Done et al., 2007; Smith, Gilmour, and Heyward, 2008). However, various investigations show that these inshore reefs can support diverse and distinctive coral assemblages adapted to elevated sedimentation and turbidity conditions

DOI: 10.2112/JCOASTRES-D-11-00171.1 received 18 September 2011; accepted in revision 26 February 2012.

Published Pre-print online 6 June 2012.

(c) Coastal Education \& Research Foundation 2012
(Ayling and Ayling, 1999; Perry and Smithers, 2006; Veron, 1995). Although conceptual models have been proposed to explain turbid zone reef growth and other reef types (Kleypas, Buddemeier, and Gattuso, 2001; Woolfe and Larcombe, 1999), quantitative data documenting the sediment regime where these reefs initiate and grow are rare.

Collecting reliable and representative data on sediment regimes is difficult (Jurg, 1996). Previous research has largely relied on sediment trap data, but these data can be problematic because the rate at which sediments collect in traps is reliant on trap geometry, sediment grain size, and suspended sediment concentrations (Gardner, 1980). Sediment traps also tend to collect coarse sediments and underestimate fines, and they commonly overestimate sedimentation rates in highenergy settings where resuspended sediments are trapped rather than transported farther downcurrent (Jurg, 1996; Storlazzi, Field, and Bothner, 2011; Thomas and Ridd, 2004). The balance between deposition and resuspension has major implications for coral reef health and reef accretion rates; therefore, it is important to evaluate and quantify these processes. Other techniques applied to assess sediment regimes on reefs include anchored tiles, reference to horizon 


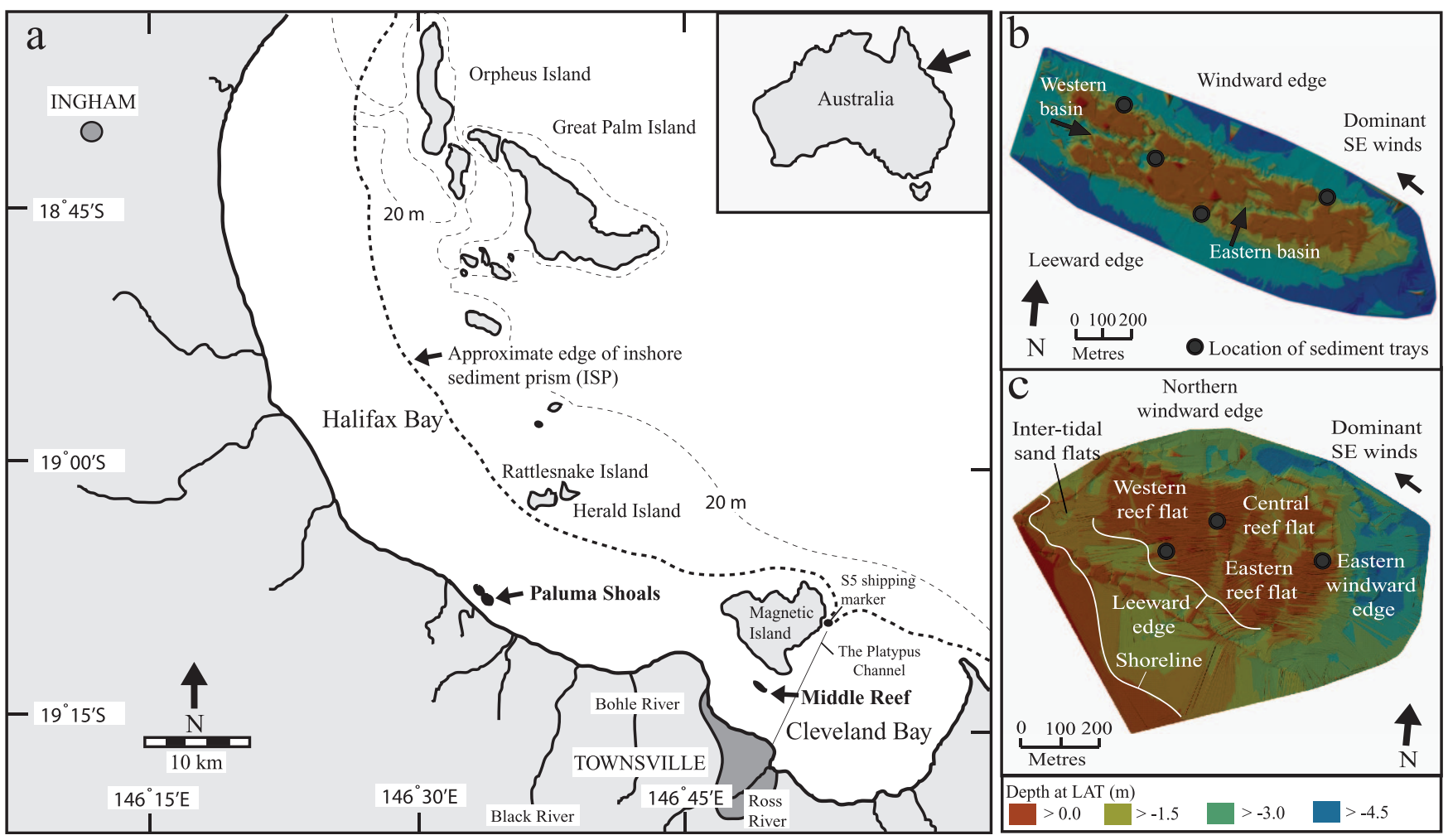

Figure 1. (a) Location of Middle Reef and Paluma Shoals on the central GBR. (b) Annotated image of Middle Reef, showing its discontinuous reef flat, two linear basins, and the base of the reef slope. (c) Annotated image of Paluma Shoals, showing the extent of the reef flat and the windward and leeward edges. (Color for this figure is only available in the online version of this paper.)

markers, and measurements of changes in suspended sediment concentrations. Sophisticated instruments like sediment accumulation sensors that continuously measure sedimentation rates (Thomas and Ridd, 2005) have also been used, but these tend to have high cost and low spatial coverage (see Thomas and Ridd, 2004, for a review).

Here, we present a new methodology to better quantify sedimentation, sediment resuspension, and fluxes across a coral reef. The approach is based on paired sediment trays that have been designed to greatly reduce problems associated with sediment traps. The trays allow for sediment deposition and resuspension and therefore assessment of net depositional rates. They do not, however, account for sediment advection past the trays and measure only those sediments that settle on the reef, unlike sediment traps that may also trap sediments in suspension. An experiment was designed using paired sediment trays deployed for 1 year on two inshore turbid reefs on the GBR that experience high and fluctuating sediment loads. On deployment, one tray was covered with a known mass of preanalysed sediments, which were recovered 2 weeks later to determine shorterterm seasonal sediment resuspension rates. Specifically, we (1) assessed spatial and temporal differences in the rate of net sediment deposition, (2) described the nature of sediments deposited and resuspended, (3) distinguished between intra-annual depositional rates and annual sedimentation rates, and (4) quantified the total mass of mobile sediments at each site. Our data reveal new insights into sediment regimes on inshore turbid reefs and demonstrate the utility of this simple but effective methodology.

\section{SITE DESCRIPTION}

\section{Middle Reef}

Middle Reef $\left(19^{\circ} 11^{\prime} 70^{\prime \prime} \mathrm{S}, 146^{\circ} 48^{\prime} 70^{\prime \prime} \mathrm{E}\right)$ is located in Cleveland Bay $(<15 \mathrm{~m})$ on the central GBR, approximately $4 \mathrm{~km}$ offshore from Townsville, Australia's most populous tropical city (Figure 1a). Cleveland Bay has a 4-m-thick layer of muddy sand and sandy mud of mainly terrigenous origin deposited over a muddy Pleistocene clay unit (Carter, Johnson, and Hooper, 1993; Lou and Ridd, 1997). Swell waves are the main agent of resuspension, and resuspended sediments from the southern sections of the bay are transported northwards by tidal and wind-driven currents through the Western Channel as turbid water (Lou and Ridd, 1996). Turbidity at Middle Reef can rise to more than 20 nephelometer turbidity units (NTU) when significant wave height $\left(H_{\text {sig }}\right)$ exceeds $1 \mathrm{~m}$ for 1 or 2 days (Larcombe et al., 1995).

Middle Reef is a linear feature $(1.2 \times 0.3 \mathrm{~km})$ aligned with the dominant NW currents that flow between Magnetic Island and the mainland (Figure 1b). Two prominent linear basins (10$20 \mathrm{~m}$ wide) that are around $3 \mathrm{~m}$ deep separate four reef flats and 
provide reef-slope habitat that is relatively sheltered from high wave energy (Browne, Smithers, and Perry, 2010). Coral cover extends to approximately $3.7 \mathrm{~m}$ below lowest astronomical tide (LAT) at Middle Reef, and mean live hard coral cover across the reef was $39.5 \%$. For a comprehensive description of coral community abundance and composition, refer to Browne, Smithers, and Perry (2010).

\section{Paluma Shoals}

Paluma Shoals $\left(19^{\circ} 5^{\prime} 43^{\prime \prime} \mathrm{S}, 146^{\circ} 33^{\prime} 5^{\prime \prime} \mathrm{E}\right)$ is located in central Halifax Bay ( $<15 \mathrm{~m}$ ) approximately $30 \mathrm{~km}$ north of Townsville (Figure 1a). Halifax Bay is dominated by mixed siliclasticcarbonate sediments and is characterised by a shore-attached terrigenous sediment deposit, termed the inshore sediment prism (Belperio, 1988; Carter, Johnson, and Hooper, 1993). During the dry winter months, persistent SE trade winds generate swell (periods $>6 \mathrm{~s}$; Larcombe et al., 1995) and drive shore-parallel currents that transport sediment northwards (Larcombe and Woolfe, 1999). Maximum turbidity measurements of 175 NTU have been recorded, with an estimated 40 days per year exceeding 40 NTU (Larcombe, Costen, and Woolfe, 2001).

Paluma Shoals consists of a larger southern shoal $(500 \times$ $820 \mathrm{~m}$ ) and smaller northern shoal complex, both of which extend down to approximately $3.5 \mathrm{~m}$ below LAT on the windward slope (Palmer et al., 2010; Smithers and Larcombe, 2003). The southern shoal is a connected to the mainland at its NW end via intertidal sand flats (Figure 1c). The tops of massive Goniastrea colonies emerge when the tide is at $+0.85 \mathrm{~m}$ LAT, and the reef flat is fully exposed at $+0.5 \mathrm{~m}$ LAT. Coral cover extends to approximately $3.5 \mathrm{~m}$ below LAT at Paluma Shoals, and mean live hard coral cover was $29.2 \%(\mathrm{SE}=3.94)$. Smithers and Larcombe (2003) describe the Holocene evolution of the reef at Paluma Shoals, and a description of coral community and sedimentology is presented by Palmer et al. (2010).

\section{MATERIALS AND METHODS}

\section{Apparatus and Sediment Collection}

Each sediment tray array consisted of two stainless steel sediment trays $(35 \times 20 \mathrm{~cm}$ at the base of the tray) secured in an aluminium frame and stabilised with a $20-\mathrm{kg}$ weight attached at one end and steel pegs at the other (Figure 2). The trays were approximately $2.5 \mathrm{~cm}$ deep and were laid as close as possible to the reef substrate (maximum distance above the substrate was $2 \mathrm{~cm}$ ) within the natural relief of the surrounding reef surface. Trays were orientated with the shorter edge facing the prevailing water movement to minimise the possible influence of turbulence at the tray edge. Sediment tray arrays were deployed in September 2009 at a leeward and a windward location $(-1.5$ to $-3 \mathrm{~m})$ and at a central location at each reef (0.5 m; Figure 1). The number of paired trays were sufficient for inter- and intrareef replication (tested using one- and twoway analyses of variance) while meeting marine permit regulations. Sediments were collected from the sediment trays in situ using a handheld airlift underwater vacuum and suctioned into in a plastic container before being brought to

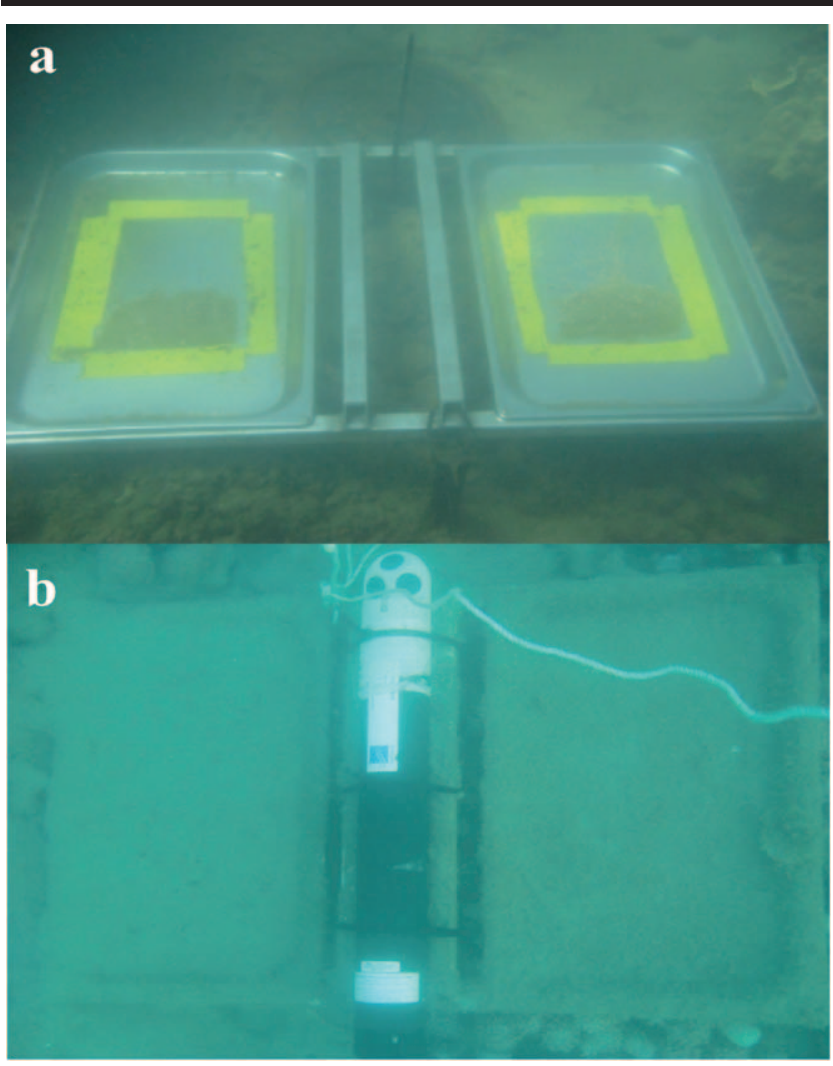

Figure 2. Sediment trays in situ. (a) Sediment trays on deployment during a trial survey period. Yellow tape was used to secure $100 \mathrm{~g}$ of sediments by a plastic sheet to the base of the sediment trays $(35 \times 20 \mathrm{~cm})$. The plastic sheet was removed once trays were stable. (b) ADCP attached across the centre of the tray frame to measure wave data. (Color for this figure is only available in the online version of this paper.)

the sea surface. Sediments were then flushed from the container into plastic bags for transport to the laboratory.

\section{Deployment Strategy}

One sediment tray on each frame was used to determine short-term seasonal variations in net sediment deposition and shorter-term resuspension rates, and the other was used to determine annual net sediment deposition and resuspension rates. On deployment, $100 \mathrm{~g}$ of mixed sediments ( $\sim 50 \%$ carbonate) of known particle-size distribution were placed on the seasonal tray to measure typical resuspension rates under normal conditions that prevail at the study reefs, while the annual sediment tray remained clear. The "known" sediments were coarser $(>100-1000 \mu \mathrm{m})$ than sediments typically deposited at each location on the reef and had been collected from the most windward regions of each reef. Coarse sediments were used to allow the identification of finer sediments $(<500 \mu \mathrm{m})$ deposited during a 2 -week period, as well as the simultaneous assessment of which particles of the original $100 \mathrm{~g}$ had been removed due to resuspension events. Using coarse sediments for this purpose yields a conservative estimate of resuspension rates because finer sediments are 
Table 1. Summary of sediment sampling schedule (S) and data logger deployment to measure turbidity (T) and wave regimes (W) at Middle Reef and Paluma Shoals over 1 year.

\begin{tabular}{|c|c|c|c|c|c|c|c|c|c|c|c|c|}
\hline \multirow[b]{2}{*}{ Reef and Site } & \multicolumn{6}{|c|}{2009} & \multicolumn{6}{|c|}{2010} \\
\hline & Sep & Oct & Nov & Dec & Jan & Feb & Mar & Apr & May & Jun & Jul & Aug \\
\hline \multicolumn{13}{|l|}{ Middle Reef } \\
\hline Eastern windward & $\mathrm{S}$ & & $\mathrm{S}$ & & & $\mathrm{W}, \mathrm{T}, \mathrm{S}$ & & $\mathrm{W}, \mathrm{T}, \mathrm{S}$ & $\mathrm{S}$ & $\mathrm{S}$ & & $\mathrm{S}$ \\
\hline Western windward & $\mathrm{W}, \mathrm{S}$ & $\mathrm{S}$ & $\mathrm{S}$ & & & $\mathrm{S}$ & & $\mathrm{S}$ & $\mathrm{S}$ & $\mathrm{W}, \mathrm{T}, \mathrm{S}$ & $\mathrm{S}$ & $\mathrm{S}$ \\
\hline Western central & $\mathrm{S}$ & & $\mathrm{S}$ & & & $\mathrm{S}$ & & $\mathrm{W}, \mathrm{T}, \mathrm{S}$ & $\mathrm{S}$ & $\mathrm{W}, \mathrm{T}, \mathrm{S}$ & $\mathrm{S}$ & $\mathrm{S}$ \\
\hline Leeward & $\mathrm{W}, \mathrm{T}, \mathrm{S}$ & & $\mathrm{S}$ & & & $\mathrm{W}, \mathrm{S}$ & & & $\mathrm{S}$ & $\mathrm{S}$ & & $\mathrm{S}$ \\
\hline \multicolumn{13}{|l|}{ Paluma Shoals } \\
\hline Central reef flat & $\mathrm{S}$ & $\mathrm{S}$ & & & $\mathrm{S}$ & & & & $\mathrm{S}$ & & & \\
\hline Leeward & $\mathrm{S}$ & $\mathrm{W}, \mathrm{S}$ & & & $\mathrm{S}$ & & & $\mathrm{S}$ & $\mathrm{S}$ & $\mathrm{S}$ & $\mathrm{W}, \mathrm{T}, \mathrm{S}$ & $\mathrm{S}$ \\
\hline Windward & $\mathrm{S}$ & $\mathrm{W}, \mathrm{S}$ & & & $\mathrm{S}$ & & & $\mathrm{W}, \mathrm{T}, \mathrm{S}$ & $\mathrm{S}$ & $\mathrm{S}$ & $\mathrm{W}, \mathrm{T}, \mathrm{S}$ & $\mathrm{S}$ \\
\hline
\end{tabular}

usually more easily resuspended. This decision was taken to allow fine sediments accumulated on the trays during this period to be identified, which would have been difficult if the original $100 \mathrm{~g}$ contained the same fraction. A 2-week time frame provided a representative sample of "normal" weather and wave conditions based on eight 1-month hydrodynamic data collection periods in Cleveland and Halifax Bay (Browne et al., unpublished data). Over the following year, sediments deposited on the seasonal depositional tray were removed every 4 to 6 weeks, depending on weather conditions and logistical considerations, but sediments on the annual sediment tray remained untouched and were allowed to accumulate or erode over the entire year. Sedimentation rates were averaged across seasons-spring (September-November), summer (DecemberFebruary), autumn (March-May), and winter (June-August) - to accommodate variations in sampling schedules imposed by weather and safety (Table 1). At the end of a year-long deployment, sediments were collected from both trays to assess and compare annual net sediment deposition and resuspension rates with seasonal deposition and resuspension rates. The total mass of sediments remaining on the annual sediment tray was lower than the cumulative mass of sediments collected from the seasonal sediment trays due to losses associated with resuspension. Clearly, the possibility exists that erosion driven by less frequent and potentially atypical resuspension events was not captured by our seasonal tray data, because sediments were collected every 4 to 6 weeks and therefore not available for resuspension during such events. Although this possibility is an unknown using this technique, over longer deployments, the impact of these events would become better known. Acknowledging this uncertainty, the difference between the annual and the seasonal depositional rates is taken as the annual resuspension rate.

\section{Sedimentary Regime Definitions and Calculations}

The key sediment regime parameters derived using the sediment trays are defined here, together with a detailed description of how each was calculated.

The seasonal sedimentation rate $\left(D_{S}\right)$ represents the mean rate of accumulation of new sediments on seasonal trays over a period greater than a full lunar cycle but less than 6 weeks. Following completion of the initial 2-week experiment (collection 1), sediments were collected from each seasonal tray up to eight times (collections 2-9). These data reveal seasonal- and event-scale variations in sedimentation rate (in grams per square metre per day) and deposited sediment grain size.

Seasonal resuspension rates $\left(R_{S}\right)$ were derived from the reanalysis of grain-size distributions of sediments collected (collection 1) from seasonal trays after they were dosed with $100 \mathrm{~g}$ of sediment of known texture and field deployed for 2 weeks in September 2009. During deployment, daily average wind speeds ranged between 10 and $30 \mathrm{~km} / \mathrm{h}$ and were predominantly from the SE. Firstly, a resuspension fraction $\left(R_{F S}\right)$ - the percentage of the original dosed sediments that have been resuspended-was determined by comparing the particle-size distribution curves of the collected and original "known" sediments. A seasonal resuspension rate (in grams per square metre per day) was then calculated by multiplying the seasonal sedimentation rate by the seasonal resuspension fraction:

$$
R_{S}=\left[D_{S} /\left(100-R_{F S}\right)\right] \times R_{F S}
$$

The net annual sediment deposition rate $\left(D_{A}\right)$ is the net sediment deposition over 1 year, determined by converting the mass of sediments collected from the annual sediment depositional trays after a 12-month deployment to an average net mass deposited in grams per square metre per day.

The annual resuspension rate $\left(R_{A}\right)$ represents resuspension that occur over longer time frames on the annual sedimentation tray (in grams per square metre per day). The annual resuspension rate is firstly calculated by determining the percentage difference between the mean seasonal depositional rate and the annual depositional rate. The percentage or fraction calculated represents the additional mass of sediments that have been resuspended from the annual sediment tray $\left(R_{F L}\right)$ :

$$
R_{F L}=100-\left[\left(D_{A} / D_{S}\right) \times 100\right]
$$

The annual resuspension rate is then calculated by multiplying the net annual deposition rate by the annual resuspension fraction:

$$
R_{A}=\left[D_{L} /\left(100-R_{F L}\right)\right] \times R_{F L}
$$

Two-way total sediment flux $(F)$ describes the total mass of sediment that has been deposited and resuspended at a site (in 
grams per square metre per day). It is calculated as the total mass of sediments that have been deposited and resuspended following both seasonal and annual resuspension events:

$$
F=R_{S}+R_{A}
$$

\section{Particle-Size Analysis}

Sediments were dried at $55^{\circ} \mathrm{C}$ for 24 to 48 hours, weighed (to the nearest $0.001 \mathrm{~g}$ ), and analysed for particle-size distribution. Prior to particle-size analysis, sediments were soaked overnight in a dispersing agent (5\% Calgon solution) to break up aggregates. Particle size was determined using a Malvern Mastersizer X laser particle sizer for fine sediments and a rapid sediment analyser settling tube for the coarser sediment fraction. The Malvern Mastersizer X is capable of assessing particle sizes accurately to $0.02 \mu \mathrm{m}$ but can only be used for fine sediments ( $<500 \mu \mathrm{m}$; Woolfe and Michibayashi, 1995). Prior to particle-size analysis, sediment samples were weighed and wet sieved into a fine and coarse fraction using a $420-\mu \mathrm{m}$ sieve to ensure that the fine-sediment fraction was well within the Mastersizer limitations. The coarse fraction $(>420 \mu \mathrm{m})$ was oven dried and reweighed to determine its proportion by weight of the original sample. Subsamples of the coarse (10-15 g) and wet fine (10-20 ml) fractions were then used to determined the particle-size distributions of the fractions that were larger and less than $420 \mu \mathrm{m}$, respectively, before the data were combined using Gradistat software to produce a particle-size distribution curve for the total sample (Blott and Pye, 2001).

\section{Hydrodynamics}

Wind-driven waves are the dominant control of sedimentary regimes on the inner GBR (Lou and Ridd, 1997; Orpin et al., 2004). Half-hourly wind data for Cleveland Bay was collected by the Australian Institute of Marine Science (AIMS) weather station on the S5 Platypus shipping channel marker (Figure 1a). Wave measurements were collected using a Nortek 2$\mathrm{MHz}$ acoustic Doppler current profiler (ADCP) programmed to record every 20 minutes during deployment periods. Measurements included the significant and maximum wave height, the mean and peak wave period, and the mean wave direction. The sampling frequency was $2 \mathrm{~Hz}$, and the burst length was 512 seconds. Current data were also collected but have not been included for analysis, because velocities were typically below $5 \mathrm{~cm} / \mathrm{s}$ at the seabed and less than $10 \mathrm{~cm} / \mathrm{s}$ at the water surface. ADCPs were carefully mounted onto the aluminium frame between the two sediment trays. In this position, they present minimum disturbance to water flow over the sediment trays. Wave data were analysed using STORM, a data management, processing, and viewing tool for Nortek instruments. ADCPs were deployed for up to 2 weeks, and two deployments were carried out at each location on the reef (Table 1). ADCPs were not deployed on the reef flat at Paluma Shoals because risk of physical damage or loss of the instrument in this exposed and remote location was considered high.

\section{Turbidity}

Spatial and temporal variations in turbidity were examined. Turbidity data was collected simultaneously with wave data to identify wind and wave conditions that could potentially resuspend sediments and increase turbidity (Table 1). An optical backscatter device, commonly called a nephelometer (Ridd and Larcombe, 1994), recorded a turbidity value every 10 minutes by averaging 1000 readings taken over a 1-minute sampling period within that interval. Sensors were equipped with an antifouling wiper that was activated every 2 hours. The nephelometer was calibrated before deployment to the standard 200 NTU and mounted on a heavy steel frame that raised the instrument about $10 \mathrm{~cm}$ off the seafloor. Instruments were deployed for up to 2 weeks to capture turbidity events during the different seasons. Instruments could not be deployed at every location on the reef in every season due to the cost and the number of instruments available.

\section{RESULTS}

\section{Seasonal Sedimentation Rates}

Sedimentation rates varied significantly over Middle Reef $(F$ $(3,22)=4.46, p=0.014)$ and Paluma Shoals $(F(2,22)=5.54, p$ $=0.012$ ), with lowest mean sedimentation rates occurring on the leeward edge at Middle Reef $\left(29.8 \mathrm{~g} / \mathrm{m}^{2} / \mathrm{d}\right)$ and on the reef flat at Paluma Shoals $\left(0.9 \mathrm{~g} / \mathrm{m}^{2} / \mathrm{d}\right)$. Sedimentation rates were highest within the sheltered western central regions at Middle $\operatorname{Reef}\left(73.7 \mathrm{~g} / \mathrm{m}^{2} / \mathrm{d}\right)$ and on the protected leeward edge at Paluma Shoals (121.6 g/m²/d; Table 2). There was no significant difference in sedimentation rates over the year between Middle Reef and Paluma Shoals $(F(1,48)=0.06, p=0.82)$.

Sedimentation rates also varied seasonally, with a significant difference between summer and autumn at Middle Reef $(F$ $(9,10)=10.8, p=0.0)$ and at Paluma Shoals $(F(6,12)=2.3, p=$ $0.1)$. In general, sedimentation rates were consistently lower than the annual mean in summer and higher than it in autumn, winter, or both (Figure 3). Sedimentation rates in summer at all sites on both reefs were, with the exception of the western central basin at Middle Reef, typically less than $30 \mathrm{~g} /$ $\mathrm{m}^{2} / \mathrm{d}$. In autumn, they increased to more than $30 \mathrm{~g} / \mathrm{m}^{2} / \mathrm{d}$ at Middle Reef, with rates as high as $80 \mathrm{~g} / \mathrm{m}^{2} / \mathrm{d}$ measured in the western central basin and on the leeward reef edge at Paluma Shoals. In winter, sedimentation rates ranged from 15 to $65 \mathrm{~g} /$ $\mathrm{m}^{2} / \mathrm{d}$ at Middle Reef, with the highest sedimentation rate measured on the leeward reef edge at Paluma Shoals $\left(324 \mathrm{~g} / \mathrm{m}^{2} /\right.$ d). In spring, sedimentation rates remained high $\left(>50 \mathrm{~g} / \mathrm{m}^{2} / \mathrm{d}\right)$ within the sheltered regions of each reef (e.g., the western central basin at Middle Reef and the leeward edge at Paluma Shoals) but fell to less than $1 \mathrm{~g} / \mathrm{m}^{2} / \mathrm{d}$ in the exposed windward regions and on reef flats at both reefs.

\section{Particle-Size Distribution}

At Middle Reef, sediment texture generally fined from east to west, with medium to coarse sand $(350-710 \mu \mathrm{m})$ deposited on the eastern windward edge, very fine to medium sand on the western windward edge $(90-400 \mu \mathrm{m})$, medium silt to fine sand within the western central basin $(30-150 \mu \mathrm{m})$, and medium to coarse silt $(20-90 \mu \mathrm{m})$ deposited on the leeward edge (Table 2). There was little change in sediment texture in spring and summer on each tray, but there was an influx of coarse silt to fine sand onto the eastern windward edge and the leeward edge in autumn and 
Table 2. Site descriptions and seasonal variations in sedimentation rates for each reef site, together with calculations for mean seasonal and annual sediment deposition rates, resuspension rates, and two-way total sediment flux.

\begin{tabular}{|c|c|c|c|c|c|c|c|}
\hline & \multicolumn{4}{|c|}{ Middle Reef } & \multicolumn{3}{|c|}{ Paluma Shoals } \\
\hline \multicolumn{8}{|l|}{ Reef } \\
\hline Site description & $\begin{array}{l}\text { Eastern } \\
\text { windward }\end{array}$ & $\begin{array}{l}\text { Western } \\
\text { windward }\end{array}$ & Western central & Leeward & Windward & Reef flat & Leeward \\
\hline $\begin{array}{l}\text { Exposure to dominant } \\
\text { waves }\end{array}$ & High & Medium & Low & Medium to low & High & High & Low \\
\hline Depth (m) at LAT & -3 & -3 & -3 & -2 & -2.5 & 0.5 & -1.5 \\
\hline Hard coral cover $(\%)$ & 82 & 60 & 27 & 51 & 31 & 23 & 39 \\
\hline Dominant corals & $\begin{array}{l}\text { Acropora, } \\
\text { Montipora }\end{array}$ & $\begin{array}{l}\text { Gonipora, } \\
\text { Acropora }\end{array}$ & $\begin{array}{l}\text { Montipora, } \\
\text { Acropora, } \\
\text { Turbinaria, } \\
\text { Pachyseris }\end{array}$ & $\begin{array}{l}\text { Gonipora, } \\
\text { Acropora }\end{array}$ & $\begin{array}{l}\text { Turbinaria, } \\
\text { Acropora, } \\
\text { Montipora }\end{array}$ & $\begin{array}{l}\text { Goniastrea, } \\
\text { Platygyra, } \\
\text { Porites }\end{array}$ & $\begin{array}{l}\text { Galaxea, } \\
\text { Goniastrea, } \\
\text { Porites }\end{array}$ \\
\hline \multicolumn{8}{|l|}{ Sediment dynamics } \\
\hline $\begin{array}{l}\text { Dominant sediment } \\
\text { mode }(\mu \mathrm{m})\end{array}$ & $350-710$ & $90-400$ & $30-150$ & $20-90$ & $50-250$ & $710-1200$ & $10-90$ \\
\hline Sediment description & $\begin{array}{l}\text { Medium to } \\
\text { coarse sand }\end{array}$ & $\begin{array}{l}\text { Very fine to } \\
\text { medium sand }\end{array}$ & $\begin{array}{l}\text { Medium silt to } \\
\text { fine sand }\end{array}$ & $\begin{array}{l}\text { Medium to very } \\
\text { coarse silt }\end{array}$ & $\begin{array}{l}\text { Coarse silt to } \\
\text { medium sand }\end{array}$ & $\begin{array}{l}\text { Coarse sand to } \\
\text { very fine } \\
\text { gravel }\end{array}$ & $\begin{array}{l}\text { Medium to very } \\
\text { coarse silt }\end{array}$ \\
\hline \multicolumn{8}{|c|}{ Sedimentation rate $\left(\mathrm{g} / \mathrm{m}^{2} / \mathrm{d}, D\right)$} \\
\hline Spring (Sep-Nov) & $0 \pm 0.0$ & $51.4 \pm 0.3$ & $98.6 \pm 13.0$ & $29.1 \pm 0.0$ & $0.0 \pm 0.0$ & $0.9 \pm 0.2$ & $62.6 \pm 24.0$ \\
\hline Summer (Dec-Feb) & $27.4 \pm 6.7$ & $1.3 \pm 0.2$ & $72.0 \pm 10.1$ & $8.6 \pm 2.1$ & $2.8 \pm 1.0$ & $1.5 \pm 0.0$ & $14.0 \pm 10.0$ \\
\hline Autumn (Mar-May) & $78.2 \pm 5.2$ & $39.8 \pm 0.2$ & $109.5 \pm 7.0$ & $30.0 \pm 4.3$ & $13.4 \pm 8.3$ & $1.2 \pm 0.0$ & $85.8 \pm 70.0$ \\
\hline Winter (Jun-Aug) & $61.0 \pm 18$ & $42.9 \pm 3.6$ & $14.8 \pm 5.9$ & $51.4 \pm 10.0$ & $26.4 \pm 8.9$ & $0.0 \pm 0.0$ & $324.1 \pm 105$ \\
\hline $\begin{array}{l}\text { Mean sedimentation } \\
\quad \text { rate }\left(\mathrm{g} / \mathrm{m}^{2} / \mathrm{d}, D_{S}\right)\end{array}$ & 41.7 & 33.8 & 73.7 & 29.8 & 10.6 & 0.9 & 121.6 \\
\hline $\begin{array}{l}\text { Net annual sediment } \\
\quad \text { deposition }\left(\mathrm{g} / \mathrm{m}^{2} / \mathrm{d}, D_{A}\right)\end{array}$ & 23.3 & 8.1 & 62.1 & 4.7 & 0.0 & 0.0 & 44.1 \\
\hline $\begin{array}{l}\text { Seasonal sediment } \\
\quad \text { resuspension } \\
\quad \text { function }\left(\%, R_{F S}\right)\end{array}$ & 94 & 20 & 27 & 73 & 79 & 87 & 67 \\
\hline $\begin{array}{l}\text { Seasonal sediment } \\
\text { resuspension rate } \\
\left(\mathrm{g} / \mathrm{m}^{2} / \mathrm{d}, R_{S}\right)\end{array}$ & 626 & 9 & 27 & 80 & 40 & 6 & 251 \\
\hline $\begin{array}{l}\text { Annual sediment } \\
\quad \text { resuspension } \\
\quad \text { function }\left(\%, R_{F L}\right)\end{array}$ & 44 & 76 & 16 & 84 & 100 & 100 & 64 \\
\hline $\begin{array}{l}\text { Annual sediment } \\
\text { resuspension rate } \\
\quad\left(\mathrm{g} / \mathrm{m}^{2} / \mathrm{d}, R_{A}\right)\end{array}$ & 18 & 26 & 12 & 25 & & & 78 \\
\hline $\begin{array}{l}\text { Two-way sediment } \\
\text { flux }\left(\mathrm{g} / \mathrm{m}^{2} / \mathrm{d}, F\right)^{*}\end{array}$ & 644 & 34 & 38 & 105 & & & 329 \\
\hline
\end{tabular}

* The two-way total sediment flux cannot be calculated for the reef flat and windward location at Paluma Shoals due to $100 \%$ annual resuspension fractions.

onto the western central and windward locations in winter (Figure 4). At Paluma Shoals, coarse to very coarse sand (710-1200 $\mu \mathrm{m})$ dominated the reef flat, very fine to coarse sand $(100-700 \mu \mathrm{m})$ dominated the windward edge, and fine to coarse silt $(10-90 \mu \mathrm{m})$ dominated the leeward edge (Table 2). The texture of reef-flat sediments varied little throughout the survey period (Figure 4). However, at the leeward edge, medium to coarse sand was deposited in spring and very fine to coarse silt was deposited in summer. Mainly very fine to coarse silt was deposited along the windward edge throughout most of the year-except in winter, when very fine to medium sand was more common.

\section{Seasonal Sediment Resuspension}

At Middle Reef, the grain size of sediments resuspended from the trays varied over the reef. On the eastern windward reef edge, approximately $94 \%\left(R_{F S}\right)$ of very fine silt to very fine pebbles (Figure 5a) were resuspended, which equated to a resuspension rate of $625 \mathrm{~g} / \mathrm{m}^{2} / \mathrm{d}$. At the western windward reef edge, only $20 \%$ of sediments (fine to very coarse sand) were resuspended at a rate of $9 \mathrm{~g} / \mathrm{m}^{2} / \mathrm{d}$, and silts to very fine sand were deposited (Figure 5b). The sediment resuspension fraction $(27 \%)$ and rate $\left(27 \mathrm{~g} / \mathrm{m}^{2} / \mathrm{d}\right)$ were marginally greater in the western central basin than on the western windward edge, and resuspended sediments consisted of medium sand to very fine pebbles, whereas deposited sediments ranged from silts to very fine sand (Figure 5c). The sediment resuspension fraction increased to $73 \%$ on the leeward reef edge (very fine to very coarse sand); however, because the mean sedimentation rate was low $\left(30 \mathrm{~g} / \mathrm{m}^{2} / \mathrm{d}\right)$, the sediment resuspension rate $\left(80 \mathrm{~g} / \mathrm{m}^{2} / \mathrm{d}\right)$ was comparable to the western central basin (Figure $5 \mathrm{~d}$ ).

At Paluma Shoals, $87 \%$ of sediments (silts to very coarse sand) on the reef flat were winnowed at a rate of $6 \mathrm{~g} / \mathrm{m}^{2} / \mathrm{d}$, with limited additional deposition of fine sediments, resulting in the accumulation of very fine pebbles (Figure 5e). In contrast, 


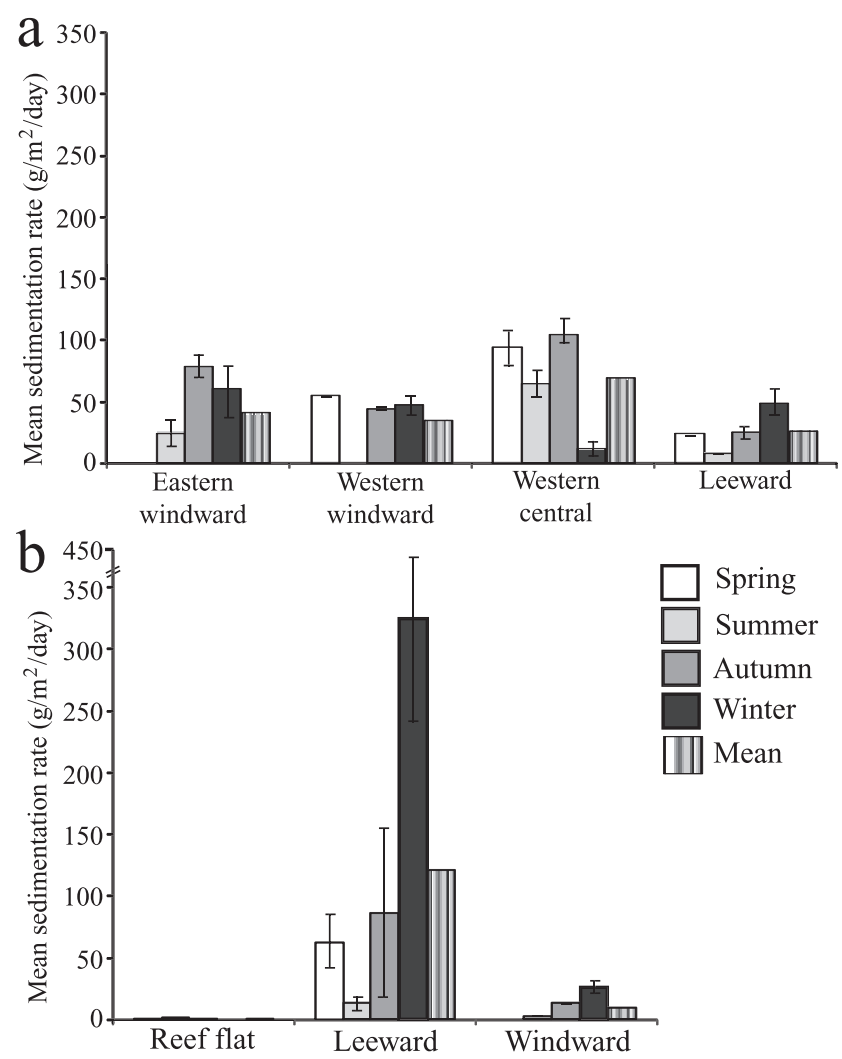

Figure 3. Mean seasonal and annual sedimentation rates at (a) Middle Reef and (b) Paluma Shoals.

$100 \%$ of very coarse sand and approximately $80 \%$ of medium sand were resuspended on the leeward and windward edges, and a large amount of silts and very fine sand was deposited (Figure $5 \mathrm{f}$ and $\mathrm{g}$ ). The resuspension rate varied between the windward edge $\left(40 \mathrm{~g} / \mathrm{m}^{2} / \mathrm{d}\right)$ and the leeward edge $\left(251 \mathrm{~g} / \mathrm{m}^{2} / \mathrm{d}\right)$ due to differences in the mean sedimentation rate.

\section{Net Annual Sediment Deposition and \\ Resuspension Rates}

Sediment deposition on the net annual depositional tray deployed for 12 months was consistently lower $\left(D_{A}\right)$ than the mean seasonal sediment depositional rate at all tray locations on both reefs $\left(D_{S}\right.$; Table 2$)$. On the eastern windward edge of Middle Reef, an average of $23.3 \mathrm{~g} / \mathrm{m}^{2} / \mathrm{d}$ was deposited on the annual depositional tray, compared to an average of $41.7 \mathrm{~g} / \mathrm{m}^{2} / \mathrm{d}$ on the seasonal depositional tray. These data suggest that over the year, $44 \%$ of sediments $\left(R_{F L}\right)$ originally deposited and accumulated during seasonal sampling intervals were later resuspended and exported off the reef surface at an average rate of $18 \mathrm{~g} / \mathrm{m}^{2} / \mathrm{d}$ (Table 2). Particle-distribution curves of the sediments collected from the net annual depositional tray and the sum of all sediments collected from the seasonal depositional tray over the year indicated that very fine to coarse sand was preferentially resuspended and redistributed (Figure 6a). On the western windward edge, the net annual sediment deposition rate was $8.1 \mathrm{~g} / \mathrm{m}^{2} / \mathrm{d}$, indicating that longer-term annual resuspension removed $76 \%$ of sediments at a rate of $26 \mathrm{~g} / \mathrm{m}^{2} / \mathrm{d}$. However, particle distribution curves of sediments on both trays were similar, suggesting that all sediment sizes were being resuspended to some degree (Figure 6b). In the western central basin, the net annual sediment deposition rate was $62.1 \mathrm{~g} / \mathrm{m}^{2} / \mathrm{d}$ and only $16 \%$ of deposited sediments, consisting of very fine to medium sediments, were resuspended at a rate of $12 \mathrm{~g} / \mathrm{m}^{2} / \mathrm{d}$ (Figure 6c). In contrast, the leeward edge had a low net annual sediment deposition rate $\left(4.7 \mathrm{~g} / \mathrm{m}^{2} / \mathrm{d}\right)$ and a high sediment resuspension rate $\left(25 \mathrm{~g} / \mathrm{m}^{2} / \mathrm{d}\right.$; Figure $\left.6 \mathrm{~d}\right)$. At Paluma Shoals, a net annual sediment deposition rate was limited to the leeward edge $\left(44.1 \mathrm{~g} / \mathrm{m}^{2} / \mathrm{d}\right)$, as no sediments had accumulated on the reef flat and windward net annual deposition tray (Table 2). Annual resuspension rates could, therefore, only be calculated from the leeward edge, where $64 \%$ of sediments, consisting of silts to medium sand, were resuspended at a rate of $77 \mathrm{~g} / \mathrm{m}^{2} / \mathrm{d}$ (Figure $6 \mathrm{e}$ and $\mathrm{f}$ ).

\section{Two-Way Total Sediment Flux}

At Middle Reef, the highest two-way total sediment flux occurred at the exposed eastern windward edge $\left(643 \mathrm{~g} / \mathrm{m}^{2} / \mathrm{d}\right)$ and the lowest was along the western windward reef edge (34 g/m²/d). At Paluma Shoals, the two-way total sediment flux could only be calculated for the leeward edge $\left(329 \mathrm{~g} / \mathrm{m}^{2} /\right.$ d), because the annual resuspension rate was $100 \%$ on the reef flat and windward edge and therefore represents an unknown quantity.

\section{Wind Regime}

Daily dominant winds measured at the AIMS weather station in Cleveland Bay during the survey period (September 2009-August 2010) blew from the NE for 39 days, from the east for 110 days, from the SE for 128 days, and from the south for 63 days. Wind direction and speed varied seasonally (Figure 7). In spring (September-November 2009), wind speeds up to $30 \mathrm{~km} / \mathrm{h}$ from the NE to the SE were interspersed with winds from the NW to the SW. In the summer (December 2009February 2010), wind speeds were moderate to very strong (10$40 \mathrm{~km} / \mathrm{h}$ ) and fluctuated between the NE and the SE. Very strong winds occurred at the start of autumn (10 days in March), with $>30 \mathrm{~km} / \mathrm{h}$ average wind speeds, but wind speeds abated in April and May to less than $25 \mathrm{~km} / \mathrm{h}$ and were typically from the SE. In winter (June-August 2010), the winds blew consistently from the SE but varied in strength from calm to strong $(5-30 \mathrm{~km} / \mathrm{h})$.

\section{Turbidity Regime \\ Middle Reef}

Turbidity responses to wind-driven waves varied spatially over Middle Reef. Turbidity along the eastern windward edge was measured in late summer (17-25 February 2010) when moderate to strong winds $(10-40 \mathrm{~km} / \mathrm{h}$ ) fluctuated between the SE and the NE (Figure 8a). Turbidity was low $(<2 \mathrm{NTU})$ until NE winds exceeding $25 \mathrm{~km} / \mathrm{h}$ occurred (19 February 2010) that generated wave heights greater than $0.8 \mathrm{~m}$. At this time, turbidity rose sharply to more than 15 


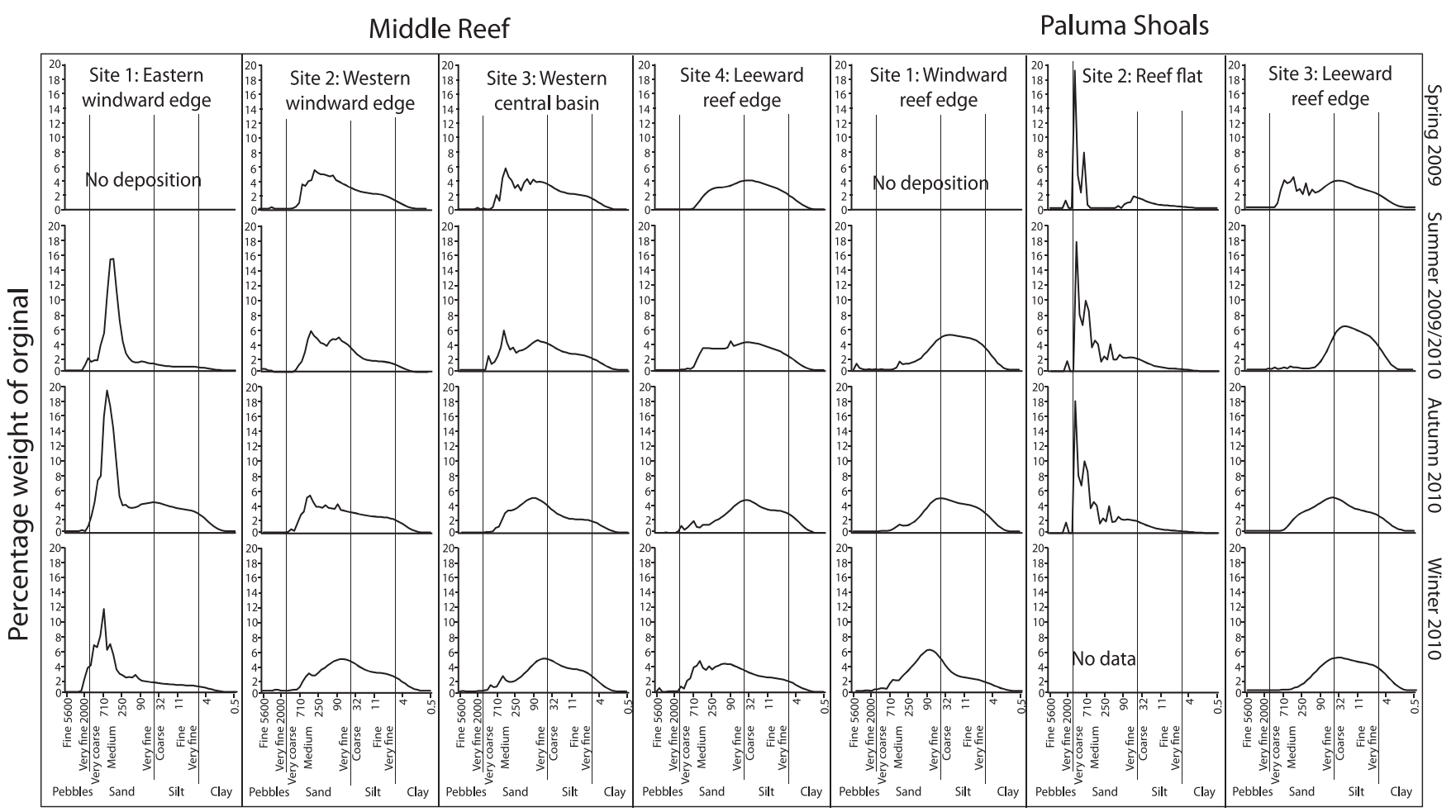

Figure 4. The mean particle-size distribution of sediments collected every 4 to 6 weeks to give the seasonal average for spring, summer, autumn, and winter.

NTU for a couple of hours before falling to approximately 5 NTU for the rest of the day and finally returning to less than 2 NTU the following day. Turbidity at the western windward and central locations was measured in midwinter (12-22 June 2010), when calm to strong winds $(5-20 \mathrm{~km} / \mathrm{h})$ blew from the south, interspersed with moderate to strong winds from the SE (10-30 km/h; Figure 8b). Turbidity was low at both locations $(<5 \mathrm{NTU})$ until strong SE winds $(>30 \mathrm{~km} / \mathrm{h})$ occurred on 16 June 2010. This increased turbidity to more than 20 NTU on the western windward edge, where wave heights reached above $0.6 \mathrm{~m}$, and greater than $40 \mathrm{NTU}$ in the western central basin, despite lower wave heights of 0.5 to $0.6 \mathrm{~m}$. Turbidity on the leeward edge was measured in spring (14-26 September 2009) when moderate NE winds $(<15 \mathrm{~km} / \mathrm{h})$ were interspersed with periods of calmer northerly winds $(<10 \mathrm{~km} / \mathrm{h} ;$ Figure $8 \mathrm{c})$. Turbidity was typically less than $3 \mathrm{NTU}$, only increasing to more than 10 NTU following a few hours of strong southerly winds $(>20 \mathrm{~km} / \mathrm{h})$. After the initial increase in turbidity, turbidity exceeded $10 \mathrm{NTU}$ for approximately 24 hours, despite a relatively rapid fall in wind speeds $(30-15 \mathrm{~km} / \mathrm{h})$ and wave heights $(>0.5 \mathrm{~m}$ to $<0.2 \mathrm{~m}$; Figure $8 \mathrm{c})$.

\section{Paluma Shoals}

Turbidity was measured at the leeward and the windward edges of Paluma Shoals in winter (29 June-9 July 2010), when wind speeds ranged from 10 to $30 \mathrm{~km} / \mathrm{h}$ from $\mathrm{E}$ to $\mathrm{S}$ (Figure 8d). Turbidity was low during calm wind speeds
$(<10 \mathrm{~km} / \mathrm{h})$ but increased at both locations ( $>100 \mathrm{NTU})$ when wind speeds increased to more than $20 \mathrm{~km} / \mathrm{h}$. However, turbidity responses were greater along the windward edge $(>200 \mathrm{NTU})$ than on the leeward edge ( $>100 \mathrm{NTU})$ due to higher wave heights $(>0.6 \mathrm{~m})$.

\section{DISGUSSION}

\section{Seasonal Sedimentation Rates}

The sedimentation rates calculated here for Middle Reef and Paluma Shoals are markedly lower than those previously reported for inshore turbid reefs on the GBR (Table 3), despite high rainfall rates in 2009/2010 (total annual rainfall was $1989 \mathrm{~mm}$ in 2009 and $2006 \mathrm{~mm}$ in 2010; Australian Bureau of Meteorology, 2010) and typical wind speeds for the region. At Middle Reef mean sedimentation rates varied between 30 and $74 \mathrm{~g} / \mathrm{m}^{2} / \mathrm{d}$, and at Paluma Shoals rates ranged from less than 1 to $122 \mathrm{~g} / \mathrm{m}^{2} / \mathrm{d}$ (Table 2). Sediment trap data from Middle Reef collected prior to, during, and following the dredging of the Platypus Channel in 1993 measured sedimentation rates of $270 \mathrm{~g} / \mathrm{m}^{2} / \mathrm{d}$ prior to dredging and more than $600 \mathrm{~g} / \mathrm{m}^{2} / \mathrm{d}$ immediately after dredging ceased (Larcombe et al., 1994). Sedimentation rates between 26 and $3640 \mathrm{~g} / \mathrm{m}^{2} / \mathrm{d}$ have also been reported using sediment traps on the nearby fringing reefs of Magnetic Island (Mapstone et al., 1992), and sedimentation rates of approximately $120 \mathrm{~g} / \mathrm{m}^{2} / \mathrm{d}$ have been estimated just offshore of Lugger Shoal, an inshore reef located $130 \mathrm{~km}$ north of Paluma Shoals (Wolanski et al., 2008). We believe that 


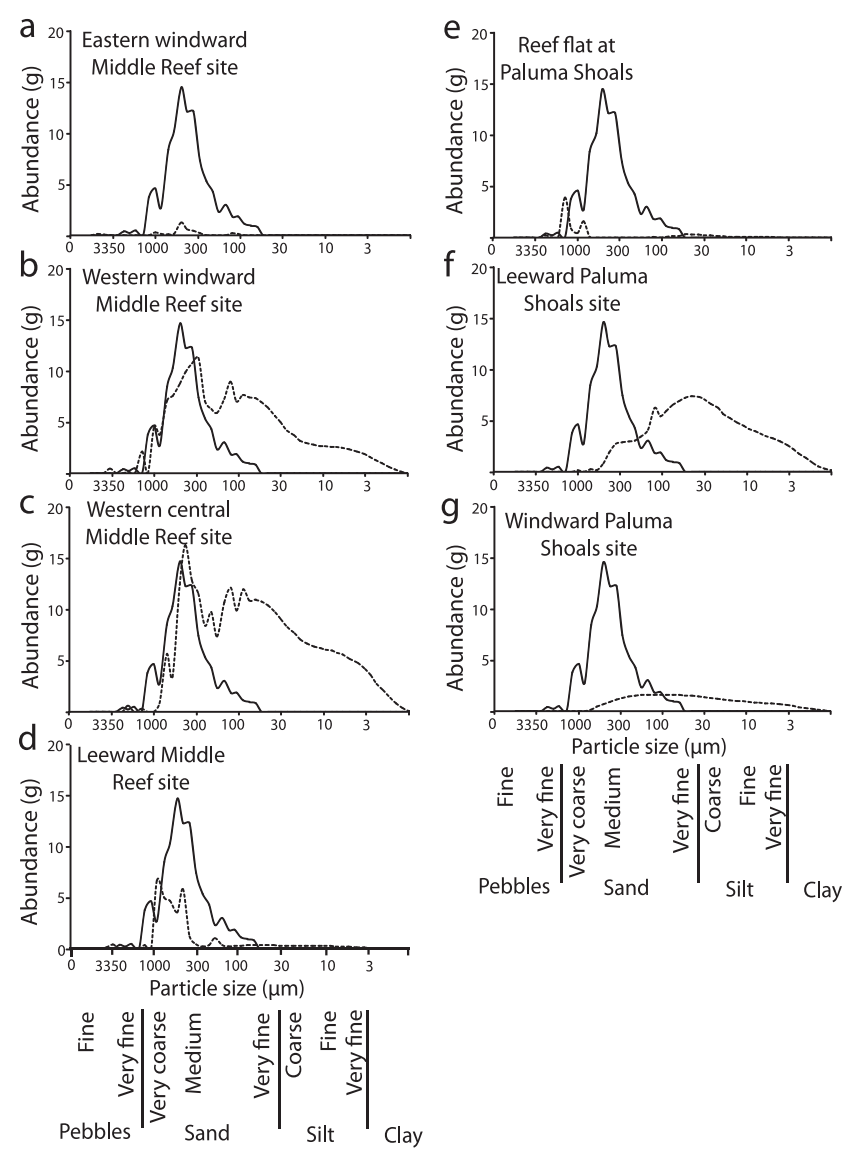

Figure 5. The particle-size distributions of sediments on the seasonal depositional tray before (continuous black line) and after (dashed line) 2 weeks in the field for (a) the eastern windward site at Middle Reef, (b) the western windward site at Middle Reef, (c) the western central site at Middle Reef, (d) the leeward site at Middle Reef, (e) the reef flat at Paluma Shoals, (f) the leeward site at Paluma Shoals and (g) the windward site at Paluma Shoals.

the higher sedimentation rates reported in these earlier studies are artefacts of the sediment trap methodology. Sediment traps modify natural hydrodynamics and do not allow for resuspension, factors that result in higher depositional rates (Thomas and Ridd, 2004, 2005; Storlazzi, Field, and Bothner, 2011). In contrast, sediment trays have been designed to reduce hydrodynamic interference and allow sediments to be transported on to and off of the receiving surface, thus providing a more accurate assessment of the natural sedimentary regime. The ability to distinguish between net sedimentation and resuspension is critical to understanding the sedimentary conditions that reef organisms are exposed to, particularly given that the negative impacts of deposited sediments are often argued to be greater than those associated with suspended sediment concentrations (Woolfe and Larcombe, 1999).

Sedimentation rates during the wet, summer months were typically lower at Middle Reef and Paluma Shoals than during the dry autumn and winter months, although previous investigations reported the converse due to increased sediment delivery to the coast from flood plumes during the wet season.
For example, in the 2007 wet season, persistently high sedimentation rates of greater than $340 \mathrm{~g} / \mathrm{m}^{2} / \mathrm{d}$ were recorded on the leeward sides of Dunk and Bedarra Islands situated approximately $10 \mathrm{~km}$ from the Tully River (which delivers $\sim 130,000$ tonnes of sediments per year; Furnas, 2003) and $140 \mathrm{~km}$ north of Paluma Shoals (Wolanski et al., 2008). Sediment delivery to Middle Reef from river runoff (Burdekin River, Ross River, and Alligator Creek) into Cleveland Bay is estimated to be 62,400 tonnes annually (Lambrechts et al., 2010), the majority of which would have been delivered to Cleveland Bay during the wet summer months $(>500 \mathrm{~mm} / \mathrm{mo}$ rainfall in January 2010; Australian Bureau of Meteorology, 2010). This sediment delivery rate equates to approximately half that from the Tully River; however, summer sedimentation rates at Middle Reef $\left(1-72 \mathrm{~g} / \mathrm{m}^{2} / \mathrm{d}\right)$ were far less than half the rates at Dunk and Bedarra Islands. Sedimentation rates remained low at Middle Reef due to strong NE to SE winds ( $>20 \mathrm{~km} / \mathrm{h}$; Figure 7 ) which typically raise wave heights to above $0.6 \mathrm{~m}$ (Figure 8) and have kept sediments in suspension. These data further indicate that the net sedimentation rate on these systems is far lower than that from previous estimates based on sediment traps, particularly during high sediment delivery and flow conditions when sediment resuspension rates are high.

At Middle Reef and Paluma Shoals, the mean grain size deposited varied over the reef due to spatial variations in wave energy, with coarser sediments deposited and accumulating on windward locations and fine sediments deposited on protected leeward edges and inner basins. Similarly, variations in grain size between seasons followed changes in wind and wave conditions. In autumn, fine silt and sand were deposited on Middle Reef's windward edge when SE wind speeds dropped to less than $20 \mathrm{~km} / \mathrm{h}$. In spring, medium to coarse sand was deposited on the leeward edge at Paluma Shoals when NE to SE wind speeds exceeded $20 \mathrm{~km} / \mathrm{h}$. It is important to consider the size of sediments delivered, together with sedimentation rates, because fine sediments associated with elevated nutrient loads may form "marine snow" with amplified negative consequences for reef benthos (Fabricius and Wolanski, 2000). Since European settlement, the delivery of fine sediments and nutrients to inshore regions has increased (Lewis et al., 2007; McCulloch et al., 2003); therefore, improved understanding of sediment particle-size distribution over reefs is critical to understanding risks and impacts. Reef habitats dominated by fine sediment deposition may be more threatened than habitats dominated by coarse sediments due to both higher sedimentation rates and increased nutrient concentrations. Similar analysis is difficult to undertake with sediment traps because they preferentially collect larger particles (Storlazzi, Field, and Bothner, 2011).

\section{Seasonal Sediment Resuspension}

Seasonal resuspension rates at Middle Reef and Paluma Shoals reflected spatial differences in sediment composition and hydrodynamics between reef locations. At Middle Reef, the proportion of sediments resuspended (94\%) and the average resuspension rate $\left(625 \mathrm{~g} / \mathrm{m}^{2} / \mathrm{d}\right)$ were greatest on the exposed eastern windward reef edge where silts and fine sand were 


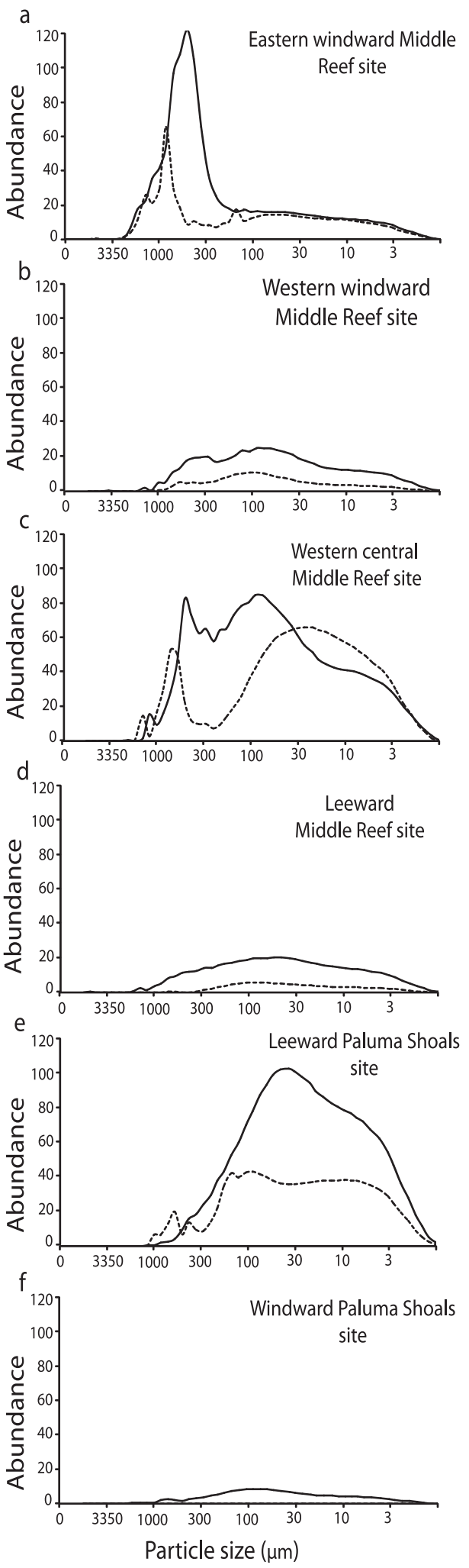

Figure 6. The difference in the particle-size distribution between the gross sediment deposited on the seasonal depositional tray (continuous line) and the sediment accumulated on the net annual accumulation tray winnowed away, leaving medium to coarse sand. These coarser sediments were less easily resuspended, and as such, turbidity was low and stable, only rising to 10 to $20 \mathrm{NTU}$ when wave heights exceeded $1 \mathrm{~m}$. In contrast, the proportion $(27 \%)$ and the rate $\left(27 \mathrm{~g} / \mathrm{m}^{2} / \mathrm{d}\right)$ of sediments resuspended within the western central basin were low due to lower wave activity. However, sediments in the western central basin are dominated by fine silt and sand, which are rapidly resuspended and produce large fluctuations in turbidity ( $>30$ NTU). Here, corals must withstand short periods ( $<6$ hours) of low light penetration, and as suspended sediments settle, they may have to expend energy removing sediment particles from their surfaces.

At Paluma Shoals, the proportion of sediments resuspended was greater than $67 \%$ across the reef, reflecting the exposed reef location. The highest sediment resuspension rates $(251 \mathrm{~g} /$ $\mathrm{m}^{2} / \mathrm{d}$ ) occurred on the leeward edge, where sediment depositional rates were also high. In reef habitats where large quantities of fine sediments are deposited and rapidly resuspended ( $>100$ NTU), corals must cope with both extended periods of low light $(<24$ hours $)$ and sediment burial. These spatial variations in sediment resuspension and turbidity data provide a comprehensive assessment of suspended sediment regimes between reef locations, which together with coral community descriptions can be used to determine coral tolerance thresholds to sedimentary pressures.

\section{Net Annual Sediment Deposition and Resuspension Rates}

Net annual sediment deposition rates on Middle Reef and Paluma Shoals were low $\left(<62 \mathrm{~g} / \mathrm{m}^{2} / \mathrm{d}\right)$ and suggest that sedimentation, in the long term, is less of a threat to it and similar inshore reef coral communities than previously considered (Kleypas and Eakin, 2007; McLaughlin et al., 2003; Rogers, 1990). The net annual depositional rate was consistently lower than the mean seasonal sedimentation rate, although the difference between the two variables varied across the reef, reflecting differences in the hydrodynamic regimes between reef habitats. These hydrodynamic differences resulted in spatially variable annual resuspension rates. For example, the proportion of sediments resuspended during a 12month period was $16 \%$ in the western basin at Middle Reef but $84 \%$ on the leeward reef edge. As such, the difference between the net annual and the seasonal mean sedimentation rates was greater on the leeward edge. At Paluma Shoals, no sediments had accumulated on the reef flat and windward edge over the year, despite sediment deposition on the seasonal tray. Although shorter-term seasonal sedimentation rates are a good indication of monthly, seasonal, or both differences in sediment deposition, they do not necessarily give an accurate

$\leftarrow$

(dashed line) on the (a) the eastern windward site at Middle Reef, (b) the western windward site at Middle Reef, (c) the western central site at Middle Reef, (d) the leeward site at Middle Reef, (e) the leeward site at Paluma Shoals and $(\mathrm{g})$ the windward site at Paluma Shoals. 

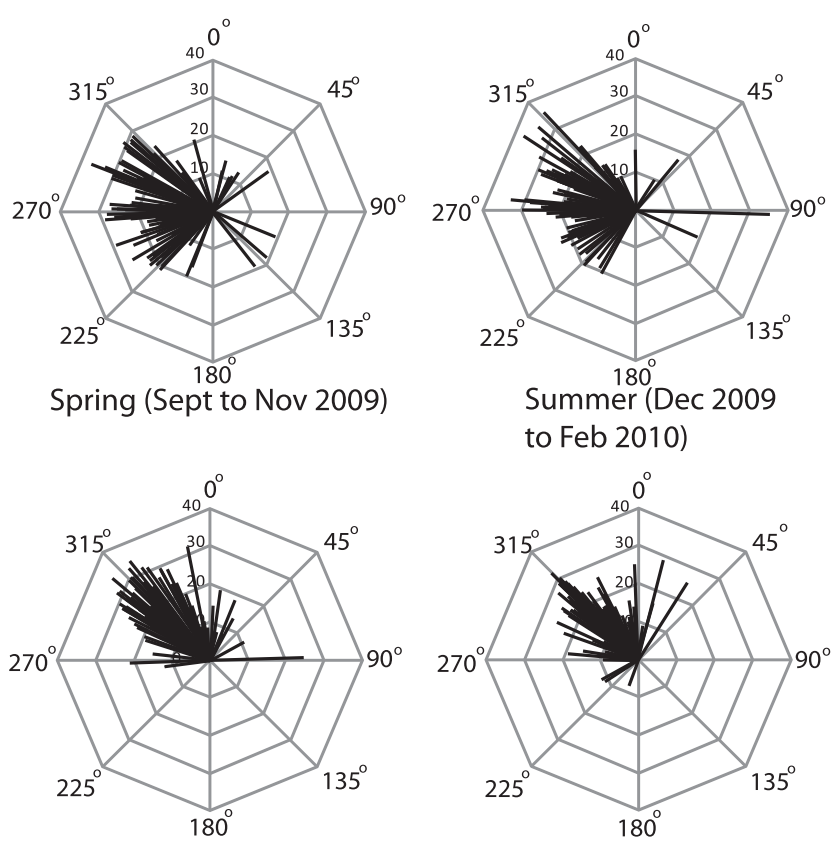

Autumn (Mar to May 2010)

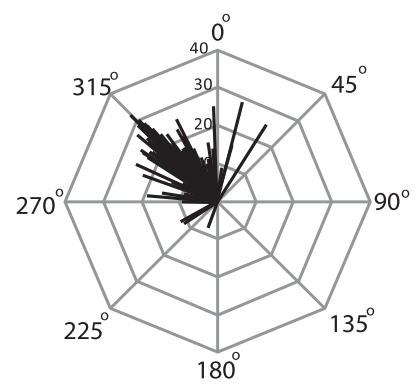

Winter (Jun to Aug 2010)

Figure 7. Wind rose indicating wind velocity (in kilometres per hour) and direction for each season during the survey period. Each branch of the rose represents the daily mean wind direction in which the wind is travelling.

indication of the longer-term buildup of sediments, particularly in highly dynamic hydrodynamic and sedimentary settings.

\section{Two-Way Total Sediment Flux}

Sediment trays measure intra-annual and annual sediment deposition and resuspension and therefore can be used to assess the total mass of mobile sediments that are both deposited and resuspended at that site. Sediments that are both deposited and resuspended are part of a flux; hence, the total mass of mobile sediments is classified as the two-way total sediment flux. At Middle Reef, the sediment flux varied between 34 and $645 \mathrm{~g} / \mathrm{m}^{2} / \mathrm{d}$, with highest rates occurring along the eastern windward reef edge. At Paluma Shoals, a single flux rate of $329 \mathrm{~g} / \mathrm{m}^{2} / \mathrm{d}$ was measured on the protected leeward edge, but given that the annual resuspension rate was higher on the windward reef edge and turbidity fluctuated to greater than 150 NTU, the flux rate is likely to be far greater here than on the leeward edge. These estimates of the total mass of sediments moving over each reef calculated with the method presented here seem sensible in view of the 21,000 t/y flux rate through Western Channel (where Middle Reef is located) suggested by recent modelling (Lambrechts et al., 2010). Furthermore, these sediment flux data have been used, together with carbonate production rates, to develop a reef growth model for inshore turbid reefs, which are typically composed of high volumes of terrigenous sediments (Browne, 2011; Palmer et al., 2010; Perry and Smithers, 2006; Smithers and Larcombe, 2003). This model generates rates of reef growth based on the tray data, which are remarkably similar to those established from radiometrically dated reef cores, providing further evidence that these data are useful and provide realistic estimates of sedimentation and flux rates on inshore turbid reefs on the GBR. The reef growth model and the chronostratigraphic reef data are written up in papers presently under review (Browne et al., unpublished data; Perry et al., unpublished data).

\section{Implications for Reef Benthos}

Spatially variable two-way total sediment fluxes, in conjunction with net annual sediment depositional rates, provide a detailed assessment of the sedimentary conditions to which corals are exposed on inshore turbid reefs. High flux rates occurred within reef habitats that were exposed to high wave activity (e.g., the eastern windward reef edge) or where fine sediments smaller than $90 \mu \mathrm{m}$ were available to be more easily resuspended (e.g., the leeward edges on both reefs). Reef habitats with high flux rates $\left(>100 \mathrm{~g} / \mathrm{m}^{2} / \mathrm{d}\right)$ and low net annual deposition $\left(<25 \mathrm{~g} / \mathrm{m}^{2} / \mathrm{d}\right)$ had high coral cover $(>50 \%)$, whereas reef habitats with high fluxes but high annual deposition of fine sediments $\left(>25 \mathrm{~g} / \mathrm{m}^{2} / \mathrm{d}\right)$ had lower coral cover $(<50 \%)$. Lowest coral cover (27\%) was observed in regions of both low flux $\left(<50 \mathrm{~g} / \mathrm{m}^{2} / \mathrm{d}\right)$ and high deposition $\left(>50 \mathrm{~g} / \mathrm{m}^{2} / \mathrm{d}\right)$. Spatial variations in coral cover ultimately influence coral carbonate productivity and reef growth.

It is widely reported that coral reefs exposed to high sedimentation (>100 g/m²/d) and high turbidity (>20 NTU) have low coral cover and diversity (Rogers, 1990); however, coral cover at Middle Reef and Paluma Shoals is greater than $29 \%$ and contains a diverse coral community ( $>50$ species; Browne, Smithers, and Perry, 2010; Veron, 1995). The coral community is spatially distributed according to the corals' ability to tolerate sedimentation and turbidity. For example, Acropora tend to dominate reef habitats where sedimentation rates $\left(<50 \mathrm{~g} / \mathrm{m}^{2} / \mathrm{d}\right)$ and turbidity $(<10 \mathrm{NTU})$ are low (e.g., the windward edge at Middle Reef), whereas Galaxea typically dominate reef habitats exposed to high sedimentation $(>50 \mathrm{~g} /$ $\mathrm{m}^{2} / \mathrm{d}$ ) and turbidity ( $>30 \mathrm{NTU}$ ) (e.g., the leeward edge at Paluma Shoals; Table 2). However, for the most part, sedimentation rates derived using sediment trays were below levels previously considered detrimental for coral reef communities (Table 2), suggesting that corals on Middle Reef and Paluma Shoals are likely not threatened by sedimentation despite high sediment loads. Furthermore, in protected reef habitats where sedimentation rates were close to and above the critical threshold of $100 \mathrm{~g} / \mathrm{m}^{2} / \mathrm{d}$ proposed by Rogers (1990), coral cover was still considered to be high ( $>30 \%$; e.g., the leeward edge at Paluma Shoals), indicating that corals in these habitats have adapted to higher deposition rates (Sofonia and Anthony, 2008). These data highlight the importance of recognising spatial variations in sedimentary regimes at the intrareefal scale and factoring in local adaptations to marginal reef growth conditions, particularly on reefs that have been exposed to naturally high sediment loads.

\section{Considerations to Sediment Tray Design}

The sediment trays and the sampling design used here improve the assessment of the sedimentary regime above that possible if standard sediment traps had been deployed, 
a
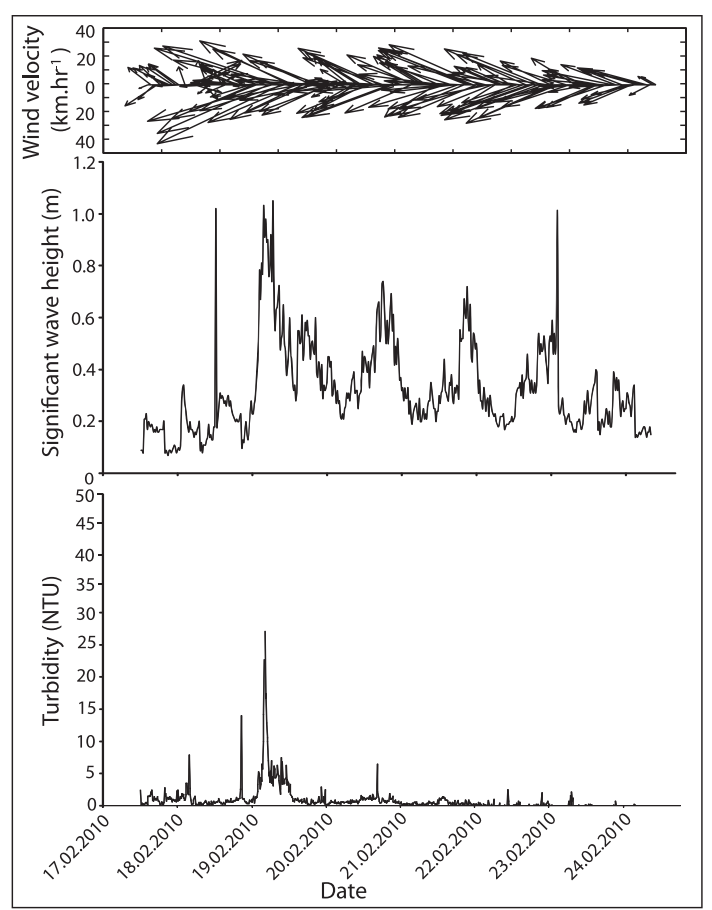

C

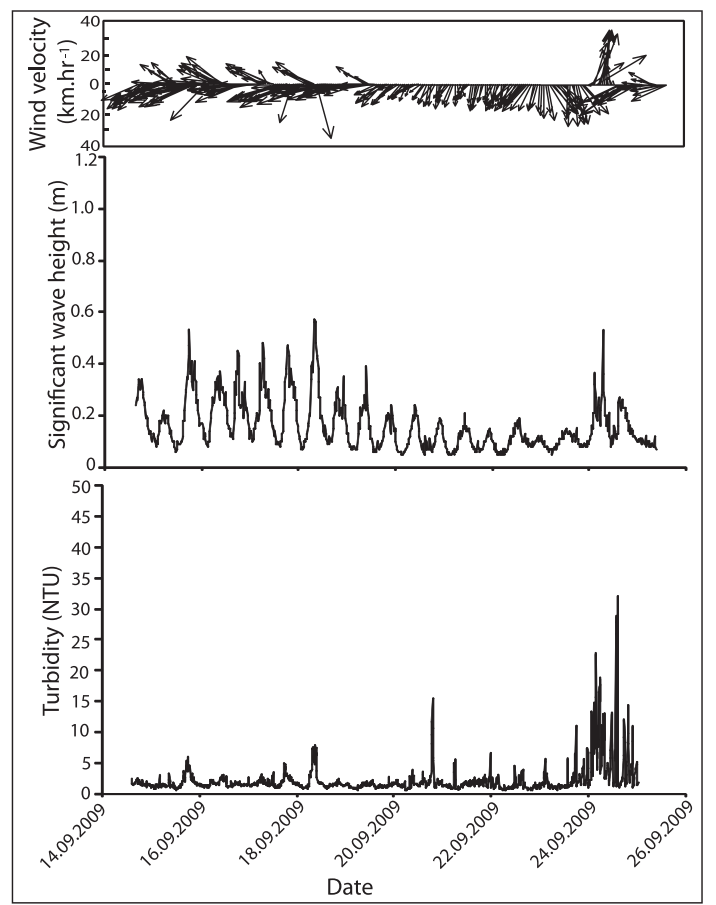

b

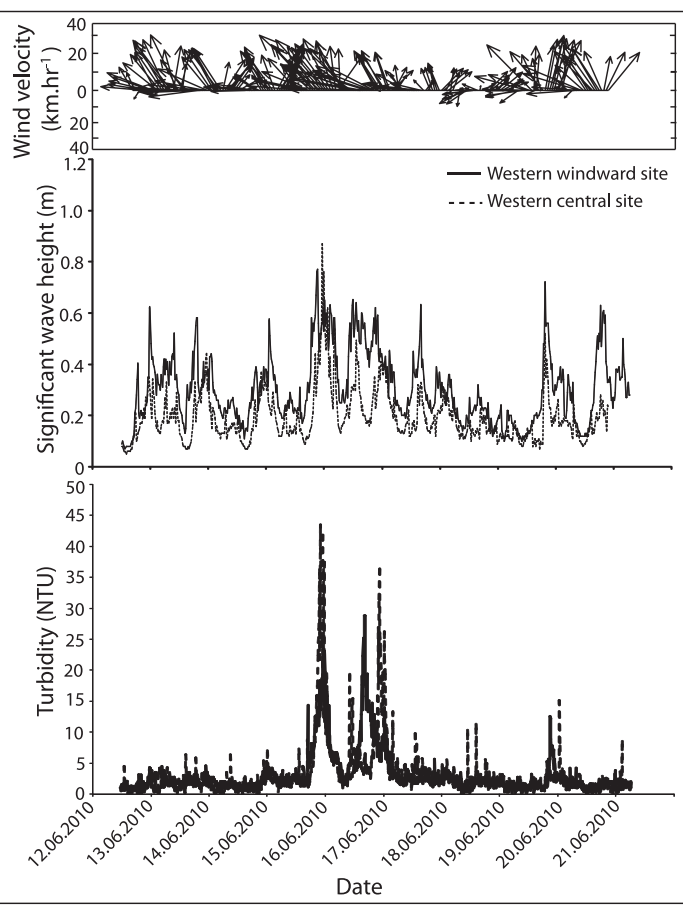

d

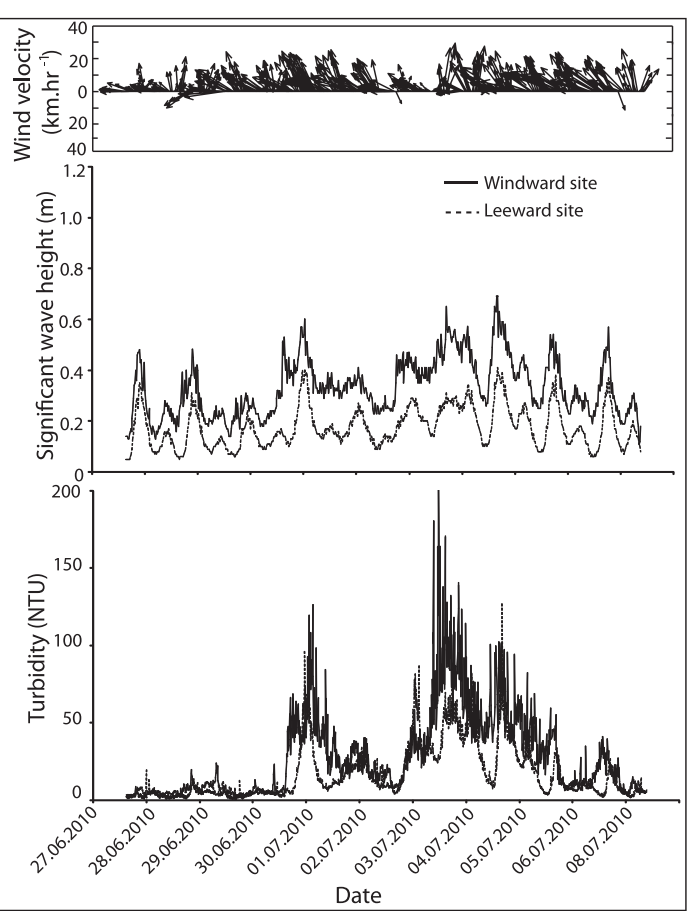

Figure 8. Wind, wave, and turbidity data for Middle Reef and Paluma Shoals. (a) Data collected at the eastern windward Middle Reef site in February 2010. (b) Data collected at the western windward and central sites at Middle Reef in June 2010. (c) Data collected at the leeward Middle Reef site in September 2009. (d) Data collected at Paluma Shoals in July 2010. Note the different turbidity scale at Paluma Shoals.

allowing both net sedimentation and shorter-term resuspension rates within a mixed terrigenous and carbonate sedimentary setting to be determined. However, during the course of the experiment, we became aware of aspects of our sediment tray design and survey protocol that can be modified to provide even greater insights.

Sediment trays were shallow $(2.5 \mathrm{~cm})$ and rectangular, held together by an aluminium frame, and deployed in pairs. 


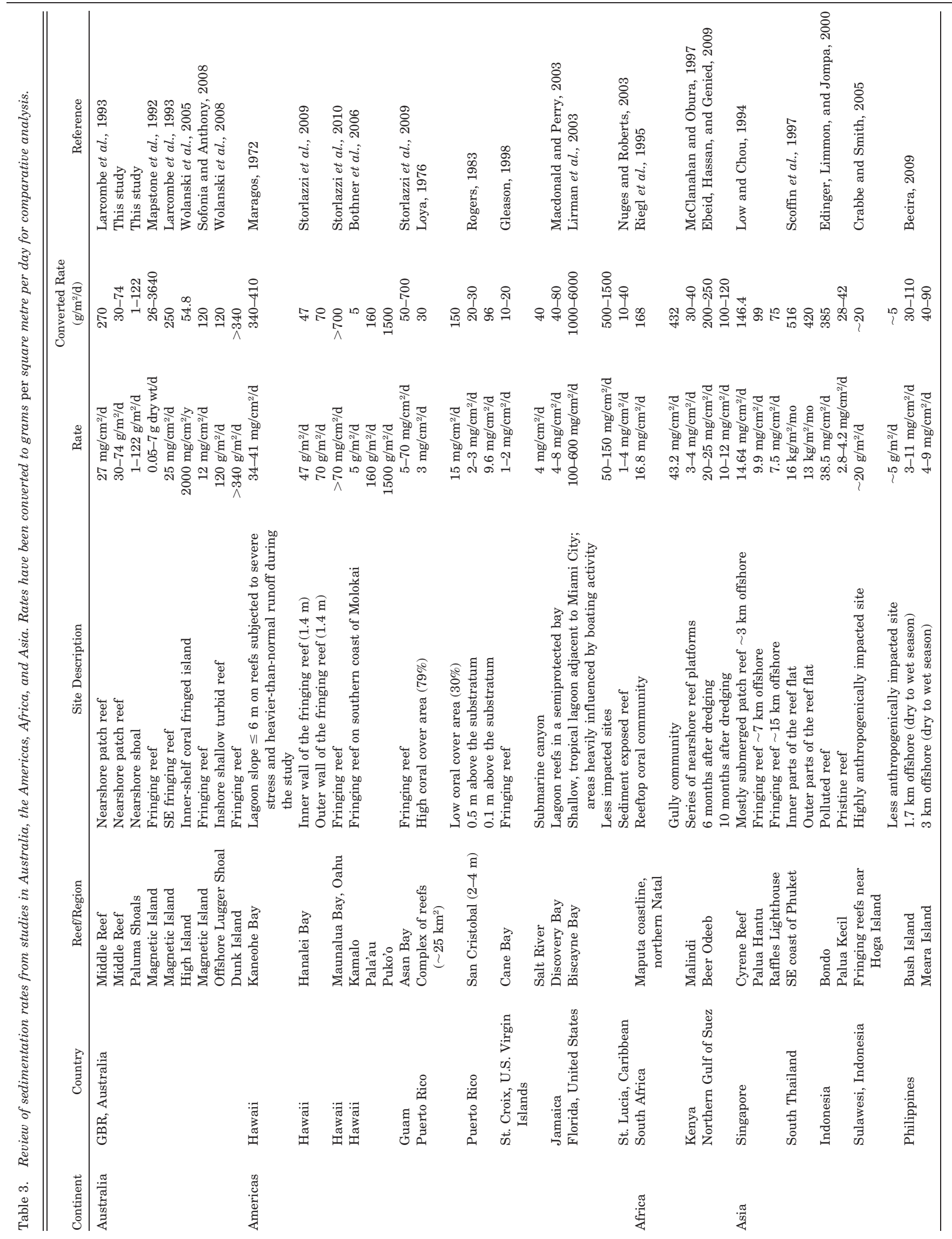


The large surface area $\left(700 \mathrm{~cm}^{2}\right)$ and shallow depth allowed for sediment resuspension, but the depth of the tray and the aluminium frame may, nonetheless, have modified the local hydrodynamics and potentially affected deposition and resuspension rates. The rectangular trays may also have had a variable influence on hydrodynamics, depending on alignment with prevailing current direction (effort was made to systematically orientate the trays with the shorter edge to oncoming currents). In the present study, we were restricted by cost and permit requirements regarding the number and type of trays that we were able to deploy. Having demonstrated the utility of this method, we now plan to investigate the influence of tray depth, size, shape, and elevation (all relative to the surrounding substrate relief and topography) on net sedimentation rates. For example, circular trays may eliminate some potential bias associated with rectangular trays. Furthermore, in this study, the decision was taken to deploy pairs of trays to measure both seasonal and longer-term annual sedimentation rates at the same site. If the two trays were separated by 10 times their diameter, as recommended for sediment traps (Gardner, 1980; Storlazzi, Field, and Bothner, 2011), the comparison of temporal differences in sedimentation rates between the two trays would not be possible given the high spatial variability in sedimentary processes across both reefs. Although the pairedtray design may confound results if the upcurrent tray influences current flow and sedimentation rates on the downstream tray, we are confident that careful orientation and the low profile of the trays compared to local reef substrate relief minimises the significance of this potential impact. We are confident that the design as is has less influence on local hydrodynamics than standard sediment traps and thus provides better understanding of sedimentary dynamics on our study reefs. Application of this technique in other sedimentary settings may require modifications to tray design relevant to the specific environment.

The experimental design used to quantify resuspension rates from sediment trays depends on both location characteristics (e.g., sediment type and hydrodynamics) and research objectives. In this study, resuspension rates were assessed during a 2-week period at the start of deployment using $100 \mathrm{~g}$ of sediments previously collected from the reefs. Two weeks provided an adequate time frame in which to capture typical wind and wave conditions (i.e., not extreme weather conditions) and assess sediment responses. This one-off measurement was taken as a proxy for shorter-term seasonal sedimentation rates over the course of the year; however, we recognise that the assessment of shorter-term seasonal resuspension rates can be improved by increasing the frequency of measurements. In addition, the time frame can be lengthened or shortened depending on local sedimentary and hydrodynamic conditions. For example, resuspension rates could be measured over a 24-hour period and compared weekly to provide a fine-scale assessment of sediment processes in highly dynamic sedimentary settings. In summary, the sediment trays provide a conservative proxy for shorter-term seasonal sediment resuspension rates, which cannot be obtained from sediment traps, and the design approach can be modified to meet local considerations and user needs.

\section{CONGLUSION}

Sediment trays provided quantitative data on a number of sedimentary parameters to provide a comprehensive assessment of sediment regimes on inshore turbid reefs. The technique is novel in that it quantifies both intra-annual and annual sedimentation rates, sediment resuspension, and twoway total sediment fluxes. The application of sediment trays overcomes a number of disadvantages associated with sediment traps (e.g., overestimation) and allows the user to distinguish between key sediment processes important for the interpretation of environmental consequences. The technique is robust yet simple and involves minimal costs to build and maintain. Sediment trays were deployed in the field for a year, and sediments were sampled every 4 to 6 weeks. A more field-intensive survey design would provide additional information on shorter-term depositional and resuspension events; however, project costs and logistical considerations need to be taken into account. Ongoing experiments tailoring the sampling interval are under way, a range of artificial sampling surfaces are being trialled, and the influence of tray depth on sedimentary processes will be undertaken.

The survey design as implemented here provided a detailed analysis of sediment regimes across four seasons and between locations on two inshore turbid reefs. In doing so, it has established that prior assessments of sedimentation rates on the GBR are potentially an overestimation and that resuspension rates are an important component of the sedimentary regime that has potentially permitted corals to survive and reefs to grow in active sedimentary environments. Furthermore, our data indicate that sedimentation and resuspension rates are highly variable spatially at the intrareef scale. Data sets of this nature improve current understanding of sedimentary regimes and provide a more accurate estimation of sedimentary conditions to which corals and other reefal organisms are exposed. A potential application of this approach could be the development of sitespecific thresholds to sediment stress for reef biota. Lastly, sediment trays have a broader applicability for use in a range of habitats, from deep sea to coastal marine and estuarine environments, where sediments play an integral role and can be adapted to suit user needs.

\section{ACKNOWLEDGMENTS}

Funding for this project was provided as a postgraduate student grant from the International Association of Sedimentologists and from the School of Earth and Environmental Sciences and Graduate Research School at James Cook University. The authors thank Fernanda de Faria, Amelia Wenger, Irene Fuertes Jerez, and Danielle Knip for their field assistance, with special thanks to Clive Grant, Paul Giveny, and Rob Scott for their technical assistance in the construction of the sediment trays and logistical support. Review comments from Curt Storlazzi and five other reviewers greatly improved this paper. 


\section{LITERATURE GITED}

Australian Bureau of Meteorology 2010. Climate Data Online, Commonwealth Bureau of Meteorology, Melbourne, Australia, www.bom.gov.au.

Ayling, A.M. and Ayling, A.L., 1999. Medium Term Changes in Coral Populations of Fringing Reefs at Cape Tribulation. Townsville, Great Barrier Reef Marine Park Authority.

Becira, J.G., 2009. Sedimentation rates in fringing reefs of Honda Bay, Puerto Princesa City, Palawan, Philippines with reference to coral reef condition. Science Diliman, 21, 7-13.

Belperio, A.P., 1988. Terrigenous and carbonate sedimentation in the Great Barrier Reef province. In: Doyle, L.J. and Roberts, H.H. (ed.), Carbonate-Clastic Transitions. Amsterdam: Elsevier, pp. 143-174.

Blott, S.J. and Pye, K., 2001. Gradistat: a grain size distribution and statistics package for the analysis of unconsolidated sediments. Earth Surface Processes and Landforms, 26, 1237-1248.

Browne, N.K., 2011. Carbonate and Terrigenous Sediment Budgets for Inshore Turbid Reefs on the Great Barrier Reef. Townsville, Queensland, Australia: James Cook University, Ph.D. thesis, 223p.

Bother, M.H.; Reynolds, R.L.; Casso, M.A.; Storlazzi, C.D., and Field, M.E., 2006. Quantity, composition and source of sediment collected in sediment traps along the fringing coral reef off Molokai, Hawaii. Marine Pollution Bulletin, 52, 1034-1047.

Browne, N.K.; Smithers, S.G., and Perry, C.T., 2010. Geomorphology and community structure of Middle Reef, central Great Barrier Reef, Australia: an inner-shelf turbid zone reef subjected to episodic mortality events. Coral Reefs, 29, 683-689.

Carter, R.M.; Johnson, D.P., and Hooper, K.G., 1993. Episodic postglacial sea-level rise and the sedimentary evolution of a tropical continental embayment (Cleveland Bay, Great Barrier Reef shelf, Australia). Australian Journal of Earth Sciences, 40, 229-255.

Crabbe, J.C. and Smith, D.J., 2005. Sediment impacts on growth rates of Acropora and Porites corals from fringing reefs of Sulawesi, Indonesia. Coral Reefs, 24, 437-441.

Devlin, M.J. and Schaffelke, B., 2009. Spatial extent of riverine flood plumes and exposure of marine ecosystems in the Tully coastal region, Great Barrier Reef. Marine and Freshwater Research, 60, 1109-1122.

Done, T.; Turak, E.; Wakeford, M.; DeVantier, L.; McDonald, A., and Fisk, D., 2007. Decadal changes in turbid-water coral communities at Pandora Reef: loss of resilience or too soon to tell? Coral Reefs, $26,789-805$.

Ebeid, M.L.; Hassan, M.H., and Genied, Y.A., 2009. Response to increased sediment load by three coral species from the Gulf of Suez (Red Sea). Journal of Fisheries and Aquatic Science, 4, 283-245.

Edinger, E.; Limmon, G.V., and Jompa, J., 2000. Normal coral growth rates on dying reefs: are coral growth rates good indicators of reef health? Marine Pollution Bulletin, 40, 405-425.

Fabricius, K.E. and Wolanski, E., 2000. Rapid smothering of coral reef organisms by muddy marine snow. Estuarine, Coastal and Shelf Sciences, 50, 115-120.

Furnas, M., 2003. Catchment and Corals: Terrestrial Runoff to the Great Barrier Reef. Townsville, Australia: Australian Institute of Marine Science \& CRC Reef Research Centre, 334p.

Gardner, W.A., 1980. Sediment trap dynamics and calibration: a laboratory evaluation. Journal of Marine Research, 38, 17-38.

Gleason, D.F., 1998. Sedimentation and distributions of green and brown morphs of the Caribbean coral Porites astreoides Lamarck. Journal of Experimental Marine Biology and Ecology, 230, 7389.

Jurg, B., 1996. Towards a new generation of sediment traps and a better measurement/understanding of settling particle flux in lakes and oceans: a hydrodynamical protocol. Aquatic Sciences, 58, 283296 .

Kleypas, J.A. and Eakin, M.E., 2007. Scientist's perceptions of threats to coral reefs: results of a survey of coral reef researchers. Bulletin of Marine Science, 80, 419-436.

Kleypas, J.A.; Buddemeier, R.W., and Gattuso, J.P., 2001. The future of coral reefs in an age of global change. International Journal of Earth Sciences, 90, 426-437.
Lambrechts, J.; Humphrey, C.; McKinna, L.; Gourge, O.; Fabricius, K.E.; Mehta, A.J.; Lewis, S., and Wolanski, E., 2010. Importance of wave-induced bed liquefaction in the fine sediment budget of Cleveland Bay, Great Barrier Reef. Estuarine, Coastal and Shelf Science, 89, 154-162.

Larcombe, P. and Woolfe, K.J., 1999. Increased sediment supply to the Great Barrier Reef will not increase sediment accumulation at most coral reefs. Coral Reefs, 18, 163-169.

Larcombe, P.; Costen, A., and Woolfe, K.J., 2001. The hydrodynamic and sedimentary setting of near shore coral reefs, central Great Barrier Reef shelf, Australia: Paluma Shoals, a case study. Sedimentology, 48, 811-835.

Larcombe, P.; Ridd, P.V.; Wilson, B., and Prytz, A., 1994. Sediment data collection. In: Benson, L.J.; Goldsworthy, P.M.; Butler, I.R., and Oliver, J. (eds.), Townsville Port Authority Capital Dredging Works 1993: Environmental Monitoring Program. Townsville, Queensland, Australia: Townsville Port Authority, pp. 149-163.

Larcombe, P.; Ridd, P.V.; Wilson, B., and Prytz, A., 1995. Factors controlling suspended sediment on inner-shelf coral reefs, Townsville, Australia. Coral Reefs, 14, 163-171.

Lewis, S.E.; Shields, G.A.; Kamber, B.S., and Lough, J.M., 2007. A multi-trace element coral record of land-use changes in the Burdekin River catchment, NE Australia. Palaeogeography, Palaeoclimatology, Palaeoecology, 246, 471-487.

Lirman, D.; Orlando, B.; Macia, S.; Maqnzello, D.; Kaufman, L.; Biber, P., and Jones, T., 2003. Coral communities of Biscayne Bay, Florida and adjacent offshore areas: diversity, abundance, distributions and environmental correlates. Aquatic Conservation, 13 121-135.

Lou, J. and Ridd, P.V., 1996. Wave-current bottom shear stresses and sediment resuspension in Cleveland Bay, Australia. Coastal Engineering, 29, 169-186.

Lou, J. and Ridd, P.V., 1997. Modelling of suspended sediment transport in coastal areas under waves and currents. Estuarine, Coastal and Shelf Science, 45, 1-16.

Low, J.K.Y. and Chou, L.M., 1994. Sedimentation rates in Singapore waters. In: Proceedings of the Third ASEAN-Australian Symposium on Living Coral Resources (Bangkok, Thailand), Volume 2, pp. 697-701.

Loya, Y., 1976. Effects of water turbidity and sedimentation on the community structure of Puerto Rican corals. Bulletin of Marine Science, 26, 450-466.

Macdonald, I.A. and Perry, C.T., 2003. Biological degradation of coral framework in a turbid lagoon environment, Discovery Bay, north Jamaica. Coral Reef, 23, 523-535.

Mapstone, B.D.; Choat, J.H.; Cumming, R.L., and Oxley, W.G., 1992. The Fringing Reefs of Magnetic Island: Benthic Biota and Sedimentation-A Baseline Study. Research Publication No. 13 Townsville, Queensland, Australia: Great Barrier Reef Marine Park Authority, 134p

Maragos, J.E., 1972. A Study of the Ecology of Hawaiian Reef Corals. Honolulu, Hawaii: University of Hawaii, Ph.D. thesis.

McClanahan, T.R. and Obura, D., 1997. Sedimentation effects on shallow coral communities in Kenya. Journal of Experimental Marine Biology and Ecology, 209, 103-122.

McCulloch, M.; Fallon, S.; Wyndham, T.; Hendy, E.; Lough, J.M., and Barnes, D.J., 2003. Coral record of increased sediment flux to the inner Great Barrier Reef since European settlement. Nature, 421, 727-730.

McLaughlin, C.J.; Smith, C.A.; Buddemeier, R.W.; Bartley, J.D., and Maxwell, B.A., 2003. Rivers, runoff, and reefs. Global and Planetary Change, 39, 191-199.

Nuges, M.M. and Roberts, C.M., 2003. Partial mortality in massive reef corals as an indicator of sediment stress on coral reefs. Marine Pollution Bulletin, 46, 314-323.

Orpin, A.R.; Ridd, P.V.; Thomas, S.; Anthony, K.R.N.; Marshall, P., and Oliver, J., 2004. Natural turbidity variability and weather forecasts in risk management of anthropogenic sediment discharge near sensitive environments. Marine Pollution Bulletin, 49, 602612

Palmer, S.E.; Perry, C.T.; Smithers, S.G., and Gulliver, P., 2010. Internal structure and accretionary history of a nearshore, turbid- 
zone coral reef: Paluma Shoals, central Great Barrier Reef, Australia. Marine Geology, 276, 14-29.

Perry, C.T. and Smithers, S.G., 2006. Taphonomic signatures of turbid-zone reef development: Examples from Paluma Shoals and Lugger Shoal, inshore central Great Barrier Reef, Australia. Palaeogeography, Palaeoclimatology, Palaeoecology, 242, 1-20.

Ridd, P. and Larcombe, P., 1994. Biofouling control for optical backscatter suspended sediment sensors. Marine Geology, 116, 255-258.

Riegl, B.; Schleyer, M.H.; Cook, P.J., and Branch, G.M., 1995. Structure of Africa's southernmost coral communities. Bulletin of Marine Science, 56, 676-691.

Rogers, C.S., 1983. Subtidal and lethal effects of sediments applied to common Caribbean reef corals in the field. Marine Pollution Bulletin, 14, 378-382.

Rogers, C.S., 1990. Responses of coral reefs and reef organisms to sedimentation. Marine Ecology Progress Series, 62, 185-202.

Scoffin, T.P.; Brown, B.E.; Dunne, R.P., and Le Tissier, M.D.A., 1997. The controls on growth form of intertidal massive coral, Phuket, South Thailand. PALAIOS, 12, 237-248.

Smith, L.D.; Gilmour, J.P., and Heyward, A.J., 2008. Resilience of coral communities on an isolated system of reefs following catastrophic mass-bleaching. Coral Reefs, 27, 197-205.

Smithers, S.G. and Larcombe, P., 2003. Late Holocene initiation and growth of a near shore turbid-zone coral reef: Paluma Shoals, central Great Barrier Reef, Australia. Coral Reefs, 22, 499-505.

Sofonia, J.J. and Anthony, K.R.N., 2008. High-sediment tolerance in the reef coral Turbinaria mestenterina from the inner Great Barrier Reef lagoon (Australia). Estuarine, Coastal and Shelf Sciences, 78, $748-752$.

Storlazzi, C.D.; Field, M., and Bothner, M.H., 2011. The use (and misuse) of sediment traps in coral reef environments: theory, observations, and suggested protocols. Coral Reefs, 30, 23-38.

Storlazzi, C.D.; Field, M.E.; Bothner, M.H.; Presto, M.K., and Draut, A.E., 2009. Sedimentation processes in a coral reef embayment Hanalei Bay, Kauai. Marine Geology, 264, 140-151.
Storlazzi, C.D.; Presto, M.K.; Logan, J.B., and Field, M.E., 2010 Coastal circulation and sediment dynamics in Maunalua Bay, Oahu, Hawaii; measurements of waves, currents, temperature, Salinity, and turbidity: November 2008-February 2009. U.S. Geological Survey Open File Report 2012-1217, 59 p. http://pubs. ugs.gov/of/2012/1217/.

Thomas, S. and Ridd, P.V., 2004. Review of methods to measure short time scale sediment accumulation. Marine Geology, 207, 95-114.

Thomas, S. and Ridd, P., 2005. Field assessment of innovative sensor for monitoring of sediment accumulation at inshore coral reefs. Marine Pollution Bulletin, 51, 470-480.

Veron, J.E.N., 1995. Corals in Space and Time: The Biogeography and Evolution of the Scleractinia. Sydney, Australia: University of New South Wales Press, 321p.

Wolanski, E. and De'ath, G., 2005. Predicting the impact of present and future human land-use on the Great Barrier Reef. Estuarine, Coastal and Shelf Science, 64, 504-508.

Wolanski, E.; Fabricius, K.E.; Cooper, T.F., and Humphrey, C., 2008. Wet season fine sediment dynamics on the inner shelf of the Great Barrier Reef. Estuarine, Coastal and Shelf Science, 77, 755-762.

Wolanski, E.; Fabricius, K.; Spagnol, S., and Brinkman, R., 2005. Fine sediment budget on an inner-shelf coral-fringed island, Great Barrier Reef of Australia. Estuarine, Coastal and Shelf Sciences, 65, 153-158.

Woolfe, K.J. and Larcombe, P., 1999. Terrigenous sedimentation and coral reef growth: a conceptual frame work. Marine Geology, 155, $331-345$.

Woolfe, K.J. and Michibayashi, K., 1995. BASIC entropy grouping of laser-derived grain-size data. Computers \& Geosciences, 21, 447462

Woolfe, K.J.; Larcombe, P.; Orpin, A.R.; Purdon, R.G.; Michaelsen, P.; McIntyre, M., and Amjad, N., 1998. Controls upon inner-shelf sedimentation, Cape York Peninsula, in the region of $120 \mathrm{~S}$. Australian Journal of Earth Sciences, 45, 611-621. 